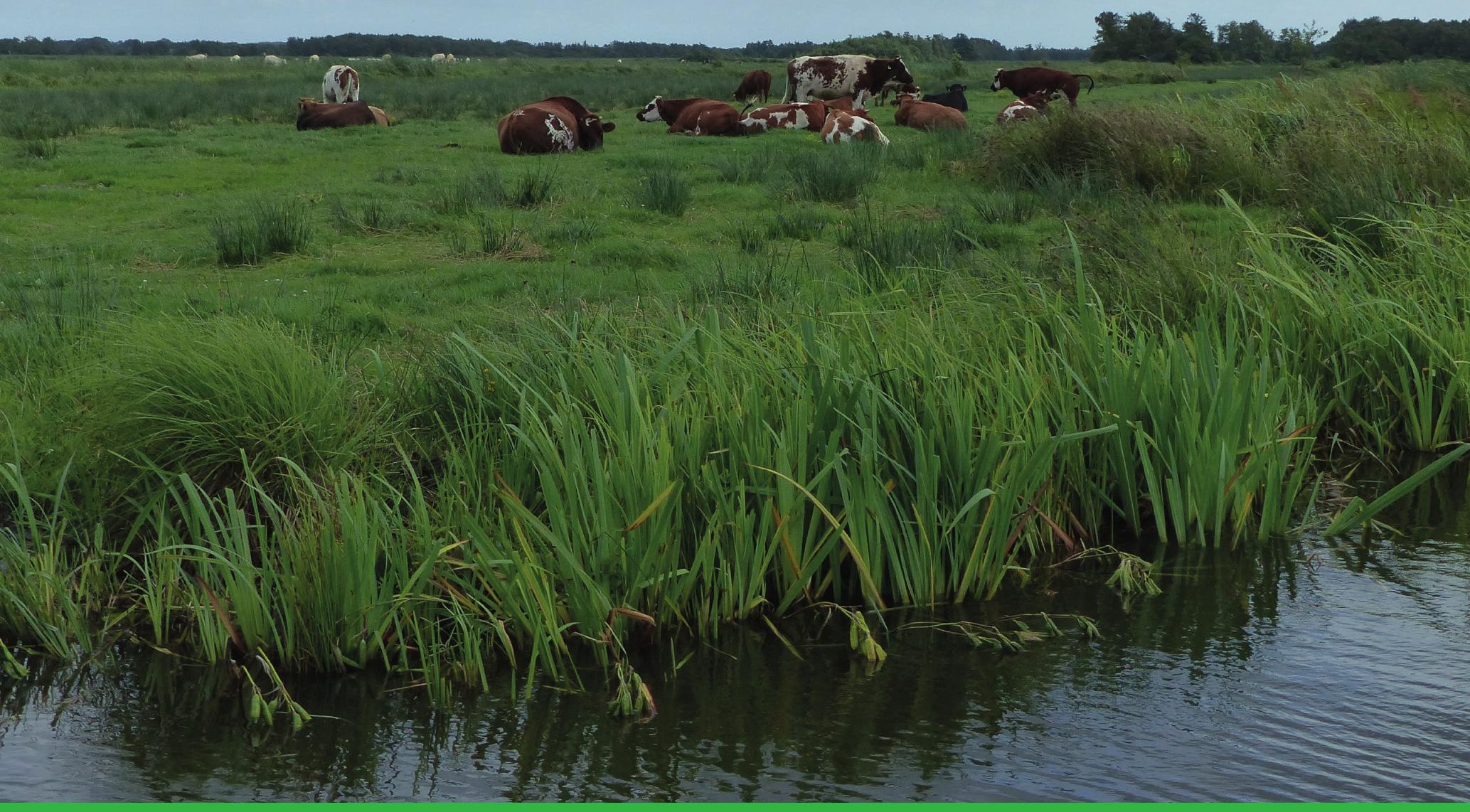

\title{
Feiten en cijfers vergroening GLB 2020
}

Berien Elbersen \& Eva de Jonge 



\section{Feiten en cijfers vergroening GLB 2020}

Berien Elbersen \& Eva de Jonge

Dit onderzoek is uitgevoerd door Wageningen Environmental Research in samenwerking met RVO en in opdracht van en gefinancierd door het Ministerie van Landbouw, Natuur en Voedselkwaliteit, in het kader van het Beleidsondersteunend Onderzoeksthema BO-43-Duurzame voedselvoorziening \& productieketen \& natuur.

Wageningen Environmental Research

Wageningen, oktober 2021

Gereviewd door:

Lysander Lantain, teamcoordinator directe betalingen GLB, Ministerie van Landbouw, Natuur en voedselkwaliteit

Akkoord voor publicatie:

Sander Janssen, teamleider van Earth Informatics team

Rapport 3119

ISSN 1566-7197 
Elbersen, B.S., Jonge, de E., 2021. Feiten en cijfers vergroening GLB 2020. Wageningen, Wageningen Environmental Research, Rapport 3119. 42 blz.; 1 fig.; 5 tab.; 9 ref.

Voorliggend rapport presenteert de uitkomsten van een monitoring van de vergroening voor het jaar 2020 volgens de geactualiseerde methode en gebruikmakend van gegevens die werden verzameld in samenwerking met RVO. De evaluatie laat zien hoe en door welke boeren maatregelen voor blijvend grasland, gewasdiversificatie en ecologische aandachtsgebieden en tevens de equivalente maatregelen zijn opgepakt. De resultaten werden geïnterpreteerd wat betreft te verwachten effecten in relatie tot de gestelde doelen van de vergroening. In de analyse worden ook de resultaten uit de voorgaande monitoringsrapportage betrokken, zodat een beeld ontstaat van de vergroening na zes jaar.

Trefwoorden: GLB, vergroening

Dit rapport is gratis te downloaden van https://doi.org/10.18174/554898 of op www.wur.nl/environmental-research (ga naar 'Wageningen Environmental Research' in de grijze balk onderaan). Wageningen Environmental Research verstrekt geen gedrukte exemplaren van rapporten.

(C) 2021 Wageningen Environmental Research (instituut binnen de rechtspersoon Stichting Wageningen Research), Postbus 47, 6700 AA Wageningen, T 03174807 00, www.wur.nl/environmental-research. Wageningen Environmental Research is onderdeel van Wageningen University \& Research.

- Overname, verveelvoudiging of openbaarmaking van deze uitgave is toegestaan mits met duidelijke bronvermelding.

- Overname, verveelvoudiging of openbaarmaking is niet toegestaan voor commerciële doeleinden en/of geldelijk gewin.

- Overname, verveelvoudiging of openbaarmaking is niet toegestaan voor die gedeelten van deze uitgave waarvan duidelijk is dat de auteursrechten liggen bij derden en/of zijn voorbehouden.

Wageningen Environmental Research aanvaardt geen aansprakelijkheid voor eventuele schade voortvloeiend uit het gebruik van de resultaten van dit onderzoek of de toepassing van de adviezen.

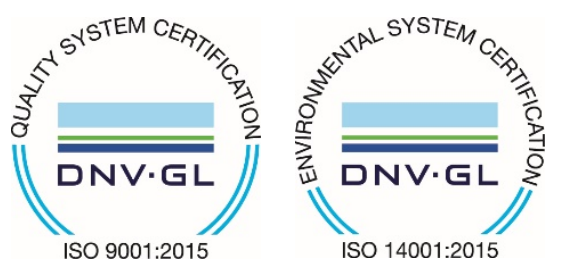

Wageningen Environmental Research werkt sinds 2003 met een ISO 9001 gecertificeerd kwaliteitsmanagementsysteem. In 2006 heeft Wageningen Environmental Research een milieuzorgsysteem geïmplementeerd, gecertificeerd volgens de norm ISO 14001.

Wageningen Environmental Research geeft via ISO 26000 invulling aan haar maatschappelijke verantwoordelijkheid.

Wageningen Environmental Research Rapport 3119 | ISSN 1566-7197

Foto omslag: Berien Elbersen 


\section{Inhoud}

Verantwoording $\quad 5$

$\begin{array}{ll}\text { Woord vooraf } & 7\end{array}$

$\begin{array}{ll}\text { Afkortingen } & 9\end{array}$

$\begin{array}{lr}\text { Samenvatting } & 11\end{array}$

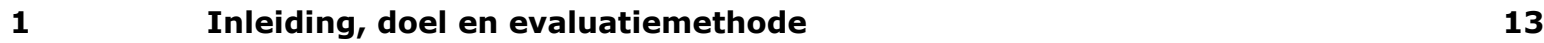

1.1 Aanleiding 13

1.2 Vergroening in het GLB $\quad 13$

1.3 Doelstellingen van vergroening in het GLB en EU-monitoring in het
Gemeenschappelijk Toezicht en Evaluatie Kader

1.4 Methode voor monitoring van vergroening in Nederlandse situatie $\quad 16$

1.5 Leeswijzer 16

$2 \quad$ Resultaten van de evaluatie en monitoring van vergroening na vier jaar

$\begin{array}{lll}2.1 & \text { Inleiding } & 17\end{array}$

2.2 Algemeen, gewasdiversificatie en equivalente maatregelen $\quad 17$

$\begin{array}{lll}2.3 & \text { Instandhouding blijvend grasland } & 21\end{array}$

$\begin{array}{lll}2.4 & \text { Ecologische aandachtsgebieden (EA) } & 24\end{array}$

$3 \quad$ Conclusies resultaten van vergroening na vijf jaar $\quad 28$

$\begin{array}{ll}\text { Literatuur } & \mathbf{3 0}\end{array}$

Bijlage 1 Invulling van vergroeningsmaatregelen in Nederland $\quad 31$

Bijlage 2 Overzicht voorwaarden en wegingsfactoren voor ecologische aandachtsgebieden 2019 (Algemene lijst) 35

Bijlage 3 Overzicht output- en resultaatindicatoren voor monitoring vergroening in GLB 



\section{Verantwoording}

Rapport: 3119

Projectnummer: 5200047122

Wageningen Environmental Research (WENR) hecht grote waarde aan de kwaliteit van zijn eindproducten. Een review van de rapporten op wetenschappelijke kwaliteit door een referent maakt standaard onderdeel uit van ons kwaliteitsbeleid.

Akkoord Referent die het rapport heeft beoordeeld,

functie: Teamcoordinator directe betalingen GLB, Ministerie van Landbouw, Natuur en Voedselkwaliteit

naam: $\quad$ Lysander Lantain

datum: 27 oktober 2021

Akkoord teamleider voor de inhoud,

naam: $\quad$ Sander Janssen

datum: 27 oktober 2021 


\section{Woord vooraf}

Dit rapport geeft antwoord op de vraag: Wat kan er na vijf jaar vergroening van het GLB gezegd worden over de resultaten en de verwachte effecten?

Zoals toegezegd door het ministerie van Landbouw, Natuur en Voedselzekerheid vanwege de Motie Ouwehand, zal er jaarlijks een rapportage naar de Kamer worden gestuurd over de effecten van de vergroening van het Gemeenschappelijk landbouwbeleid. In dit rapport worden de resultaten van de monitoring van vergroening in 2020 gepresenteerd en worden deze resultaten ook vergeleken met de uitkomsten van monitoring voor de jaren 2015-2019. Bij de beschrijving van de resultaten worden de belangrijkste bevindingen en aanbevelingen genoemd.

Dit rapport is gebaseerd op gegevens die RVO aanlevert aan de EU met betrekking tot monitoring vergroening. Hierbij wordt uitgegaan van geconstateerde (en als deze niet beschikbaar zijn, de aangevraagde) gegevens.

Wij danken dhr. Nobel en Lantain van de Directie EIA van het ministerie van Landbouw, Natuur en Voedselkwaliteit voor het voorleggen van deze vraag bij ons en voor de begeleiding. Wij danken Herman Blom voor de aanlevering van de RVO-data en de geduldige en gedegen controle op alle data en tekst in dit rapport. 


\section{Afkortingen}

\begin{tabular}{ll} 
Afkorting & Toelichting \\
BG & Blijvend grasland \\
\hline EA & Ecologisch Aandachtsgebied \\
\hline EKBG & Ecologisch Kwetsbaar Blijvend Grasland \\
\hline GLB & Gemeenschappelijk landbouwbeleid \\
\hline GTEK & Gemeenschappelijk Toezicht en Evaluatie Kader \\
\hline HNV & High Nature Value farmland \\
\hline
\end{tabular}




\section{Samenvatting}

In dit rapport worden de resultaten van de monitoring van de vergroeningsmaatregelen in 2020 gepresenteerd en worden deze vergeleken met die van 2015-2019. Deze jaarlijkse rapportage is toegezegd door het ministerie van Landbouw, Natuur en Voedselzekerheid vanwege de Motie Ouwehand, die voorschrijft dat er jaarlijks een rapportage naar de Kamer zal worden gestuurd over de effecten van de vergroeningsmaatregelen van het Gemeenschappelijk landbouwbeleid.

De vergroeningsmaatregelen werden in de hervorming van 2013 geïntroduceerd (EC COM 1307/2013) en traden in januari 2015 in werking. De vergroeningsmaatregelen beslaan $30 \%$ van de directe inkomenssteun aan landbouwbedrijven en bestaan uit:

1. Gewasdiversificatie toepassen, hetgeen een minimum aan verschillende gewassen op een bedrijf in stand houden betekent.

2. Een minimum aan ecologische aandachtsgebieden (EA) in stand houden.

3. Het in stand houden van blijvend grasland (het aandeel blijvend grasland mag landelijk niet meer dan $5 \%$ dalen en voor kwetsbare graslanden geldt een ploegverbod (blijvend grasland binnen Natura 2000-gebieden).

Tot 2020 waren er drie equivalente maatregelen waaruit de boer kon kiezen. Twee daarvan, Akkerbouwstrokenpakket en het pakket Veldleeuwerik, werden in 2015 al ingevoerd met een duurzaamheidscertificaat van het ministerie van LNV. Vanaf 2016 is daar nog een pakket, Vezelhennep, bijgekomen. Vanaf 1 januari 2020 is het pakket Veldleeuwerik echter komen te vervallen.

De vergroeningsmaatregelen hebben in Nederland een grote reikwijdte, in die zin dat een groot gedeelte van het landbouwareaal in beheer is bij boeren met minimaal één vergroeningsverplichting. Dit areaal is tussen 2015 en 2020 ook toegenomen. In 2015 had 67\% van de boeren ten minste één vergroeningsverplichting en in 2018 was dit gestegen naar 74\% en voor de jaren erna bleef het daarop stabiel. De landbouwgrond die hoort bij deze bedrijven (met minimaal één vergroeningsverplichting) bedroeg $90 \%$ in 2015, steeg naar $93 \%$ in 2016 en daalde toen naar een constant percentage van $92 \%$ vanaf 2017 t/m 2020. Gesteld kan worden dat Nederland hiermee hoog scoort in Europees perspectief, waar het gemiddelde percentage landbouwgrond dat ten minste onder één verplichting valt, op 73\% lag in 2017 (Europese Rekenkamer 2017).

Dit hoge percentage landbouwgrond met ten minste één vergroeningsverplichting wil echter niet zeggen dat er door de vergroening veel is veranderd in de landbouwpraktijk op bedrijven.

Ten eerste omdat dit percentage inclusief alle bedrijven met instandhoudingsverplichting voor blijvend grasland is (63\% van de bedrijven in Nederland). De grote meerderheid van deze bedrijven moet haar areaal blijvend gras rapporteren, maar hoeft om de vergroeningspremie te ontvangen geen aanvullende maatregelen te treffen, tenzij ze blijvend grasland heeft gelegen binnen Natura 2000gebied. Dit geldt zolang de daling van het relatief areaal blijvend grasland in het totale landbouwareaal niet meer dan 5\% bedraagt ten opzichte van het referentiejaar 2012. In 2020 was er sprake van een relatieve toename met $2,3 \%$ in dit areaal. Deze stijging hangt waarschijnlijk samen met afschaffing van het melkquotum en aanpassing van de derogatienormen.

In 2020 geldt voor $6 \%$ van de boeren met blijvend grasland een ploeg- en omzetverbod op het blijvend graslandareaal dat zij beheren in Natura 2000-gebieden. Het totaal van blijvend grasland met dit verbod, het zogenaamd Ecologisch Kwetsbaar Blijven Grasland (EKBG), is in 2020 toegenomen ten opzichte van 2015, maar is licht gedaald ten opzichte van 2018. Het areaal blijvend grasland in beheer bij boeren met EKBG-verplichting bedraagt 41677 ha in 2020 en dit betreft ook weer 5\% van het totaalareaal blijvend grasland in Nederland. Daarbij moet wel de kanttekening worden gemaakt dat Nederland $100 \%$ van het blijvend graslandareaal binnen Natura 2000 heeft aangewezen als 
kwetsbaar. Dit komt in 2020 neer op een areaal van 59804 ha ( $8 \%$ van het totale blijvend graslandareaal). Dit areaal laat dus een lichte absolute daling zien ten opzichte van 2019. Slechts een deel van dit EKBG-gebied (69\%) valt onder het beheer van vergroeningsplichtige boeren en verklaart het grote verschil tussen aangewezen hectare EKBG en opgegeven hectare onder vergroening.

Ten tweede komt gewasdiversificatie over het algemeen overeen met de gangbare landbouwpraktijk en voegt daardoor weinig toe. Tussen 2015 en 2017 steeg het aandeel boeren dat zich hieraan moet houden van $22 \%$ naar $24 \%$ en daarna is dit percentage gestabiliseerd op dit niveau. In de praktijk heeft de maatregel niet tot meer diversiteit in gewassen geleid. Een eerdere analyse (Elbersen et al., 2018) liet zien dat het gemiddelde aantal hoofdgewassen per bedrijf is afgenomen tussen 2015 en 2018.

Ten derde wordt de maatregel voor Ecologische Aandachtsgebieden (EA) op een beperkt areaal toegepast, namelijk op $11 \%$ van het landbouwareaal.

Het merendeel van de boeren in Nederland heeft, net als in voorgaande jaren, gekozen voor productiegerelateerde EA als vanggewassen en stikstofbindende gewassen ( $99 \%$ van het EA-areaal in 2020). De bijdrage van deze gewassen aan bodemkwaliteit is positief maar gering, echter aan het verbeteren van de biodiversiteit dragen zij niet bij, terwijl de EA-maatregel daar oorspronkelijk wel voor bedoeld was.

Invulling van EA via equivalente maatregelen wordt zeer weinig gekozen door boeren (nog geen $1 \%$ van de boeren kiest hiervoor) en de belangstelling hiervoor is door aanpassing in de standaardinvulling van de EA-verplichting in relatie tot vanggewassen verder gedaald vanaf 2018. Hierdoor namen de verschillen tussen de standaardinvulling en via equivalente maatregelen af en werd het minder interessant voor boeren om equivalente pakketten te kiezen (zie ook pag. 24).

Voor zowel het vastleggen van bodemkoolstof als het beschermen van onder- en bovengrondse biodiversiteit is het in stand houden van blijvend grasland belangrijk. De vergroeningsmaatregelen vanuit het GLB voor de bescherming van blijvend grasland leken ontoereikend, omdat het areaal blijvend gras een dalende trend liet zien tot 2017. In 2018 is er echter een omslag en is het areaal blijvend grasland met 0,7\% toegenomen ten opzichte van het percentage in het referentiejaar 2012 en in 2020 is de stijging zelfs 2,3\%. De stijging die dus verder doorzet in 2020, hangt zeer waarschijnlijk samen met de aanscherping van de mestnormen. ${ }^{1}$ Binnen Natura 2000 -gebieden geldt een ploeg- en omzetverbod voor blijvend gras (op 6\% van het blijvend graslandareaal). Bescherming van blijvend grasland (tegen scheuren en omzetten) geldt echter niet voor een groot deel van de weidevogel- en veenweidegebieden die vaak overlappen met zogenaamde High Nature Value farmlands, omdat die buiten Natura 2000 liggen. In deze gebieden blijft scheuren en omzetten van graslanden mogelijk en dit brengt risico's mee voor zowel de biodiversiteit als voor het vasthouden van de bodemkoolstof.

Kortom, de meerwaarde die vergroening heeft op verbetering van de bijdrage die het Gemeenschappelijk landbouwbeleid (GLB) aan EU-brede milieu- en klimaatdoelen heeft, is zeer beperkt gebleken. Dit sluit aan bij de conclusies die de Europese Rekenkamer (2017) ook al heeft getrokken na evaluatie van vergroening op EU-niveau.

\footnotetext{
1 De fosfaatgebruiksruimte op gras ligt hoger dan op bouwland. Ook voor derogatieaanvraag in 2020 (aanvraag 31 januari) geldt weer dat er een minimumareaal van $80 \%$ grasland op het bedrijf verplicht is. Bij scheuren of vernietigen (omploegen) van grasland wordt een korting op de stikstofgebruikersnorm toegepast op dat perceel. Zie: https://www.rvo.nl/sites/default/files/2019/11/Hoeveel\%20mest\%20uitrijden\%20hoe\%20rekent\%20u\%20dat\%20uit\%2 028-11-19\%20v1.pdf
} 


\section{$1 \quad$ Inleiding, doel en evaluatiemethode}

\section{$1.1 \quad$ Aanleiding}

De vergroeningsmaatregelen binnen de $1^{\mathrm{e}}$ pijler van het Europese Gemeenschappelijk landbouwbeleid werden in de hervorming van het GLB van 2013 geïntroduceerd (EC COM 1307/2013) en traden in januari 2015 in werking. In de vergroening moeten drie generieke maatregelen ervoor zorgen dat de milieuprestaties van individuele agrarische bedrijven omhooggaan. Ze werden bij de invoering in 2013 gezien als een belangrijk instrument voor verduurzaming van de Europese en daarmee ook van de Nederlandse landbouw.

In Van Doorn et al. (2015) is een systematiek voor monitoring en evaluatie vergroening op nationaal niveau uitgewerkt. De systematiek is vervolgens toegepast met een nulmeting in 2015 en ondertussen ook met een voortgangsmeting voor 2016 (Van Doorn en Smidt, 2017), 2017 (Elbersen et al., 2018), 2018 (Elbersen en Schutt, 2019) en 2019 (Elbersen en Lazebnik, 2020). In dit rapport worden de resultaten van de monitoring van vergroening in 2020 gepresenteerd en worden deze resultaten ook vergeleken met de uitkomsten van monitoring voor de jaren 2015-2019 (Elbersen en Lazebnik, 2020), waardoor een totaaloverzicht ontstaat van de resultaten van implementatie van de vergroening over een periode van zes jaar. De resultaten kunnen gebruikt worden voor de verdere uitwerking van het GLB na 2022 en voor de jaarlijkse rapportage naar de Tweede Kamer over de effecten van de vergroening van het Gemeenschappelijk landbouwbeleid, welke is toegezegd vanwege de Motie Ouwehand.

\subsection{Vergroening in het GLB}

De vergroening bestaat uit een koppeling van vergroeningsmaatregelen aan uitbetaling van $30 \%$ van de directe inkomenssteun aan landbouwbedrijven. Dit betekent dat boeren verplicht zijn vergroeningsmaatregelen toe te passen op hun bedrijf om de $30 \%$ vergroeningspremies te ontvangen boven op de basispremie.

De vergroeningsverplichtingen bestaan uit:

1. Gewasdiversificatie toepassen, hetgeen een minimum aan verschillende gewassen op een bedrijf in stand houden betekent.

2. Een minimum aan ecologische aandachtsgebieden (EA) in stand houden.

3. Het in stand houden van blijvend grasland (het aandeel blijvend grasland mag landelijk niet meer dan 5\% dalen t.o.v. het areaal in referentiejaar 2012 en voor kwetsbare graslanden geldt een ploegverbod (bijvoorbeeld blijvend gras binnen Natura 2000-gebieden).

Voor meer uitleg hierover zie ook bijlage 1.

Naast vergroeningsverplichtingen, zoals hierboven genoemd en waarop deze monitoring betrekking heeft, zijn er ook andere milieugerichte maatregelen in het kader van het GLB waar de boer zich aan moet houden of vrijwillig aan kan voldoen (zie bijvoorbeeld ook Elbersen et al., 2018; hoofdstuk 1, paragraaf 1.2). Deze milieugerichte maatregelen zijn:

1. De 'randvoorwaarden' van het GLB (in het Engels aangeduid als Cross-Compliance) waar een boer zich verplicht aan dient te houden.

2. De maatregelen die de boer vrijwillig kan kiezen, worden vergoed vanuit Pijler 2 van het GLB (Plattelandsprogramma). In Nederland omvatten deze vooral de agrarische natuurbeheermaatregelen waarvoor collectieven van boeren beheerovereenkomsten moeten afsluiten als collectief. In tegenstelling tot de vergroeningsmaatregelen die van toepassing zijn op een ruime meerderheid van agrariërs en daarbij behorend landbouwareaal, hebben vrijwillige maatregelen onder Pijler 2 een veel kleinere invloed op het landbouwareaal in Nederland. 
Vergroening is niet verplicht voor alle boeren:

- Biologische bedrijven zijn uitgezonderd van vergroening, omdat deze al worden beschouwd als groen genoeg (green by definition).

- Bedrijven met een bedrijfsareaal van minder dan 15 ha zijn vrijgesteld van het toepassen van de vergroeningsmaatregel Ecologische Aandachtsgebieden.

- Bedrijven met minder dan 10 ha bouwland hoeven geen gewasdiversificatie toe te passen.

- Boeren die een vergroeningsverplichting hebben, kunnen ook kiezen voor equivalente maatregelen. In 2019 zijn er drie equivalente maatregelen waaruit de boer kan kiezen. Twee daarvan, Akkerbouwstrokenpakket en het pakket Veldleeuwerik, werden in 2015 al ingevoerd met een duurzaamheidscertificaat van het ministerie van LNV. Vanaf 2016 is daar nog een pakket, Vezelhennep, bijgekomen (zie bijlage 1 voor meer uitleg over deze drie pakketten).

Uitgaven aan vergroening bedragen $30 \%$ van Pijler 1-uitgaven. Voor de directe betalingen vertoont het budget een dalende trend met $749 \mathrm{mln}$. euro in 2015 en $661 \mathrm{mln}$. euro in 2020. Daarvan is 30\% beschikbaar voor vergroening. Aangezien beide budgetten aan elkaar gerelateerd zijn, geldt voor beide een afname van 11\% tussen 2015 en 2020.

Tabel 1 Overzicht budget directe betalingen en budget voor vergroening tussen 2015 en 2020.

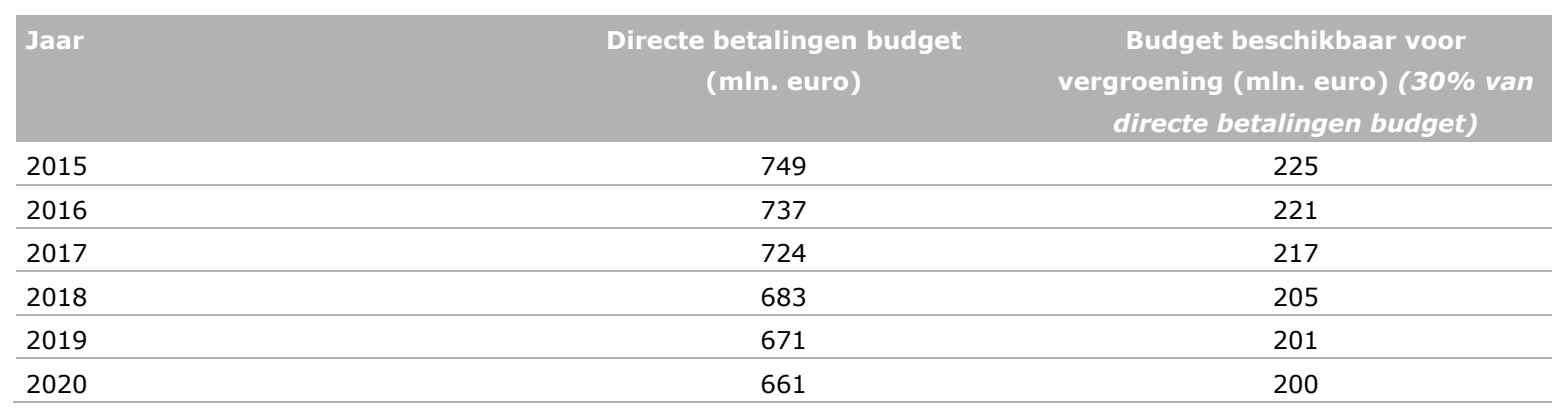

De EC-verordening (EC COM 1307/2013) biedt ruimte aan de lidstaten om de vergroeningsmaatregelen nationaal verder in te vullen. Daarom heeft Nederland zijn nationale invulling van de vergroening in 2014 vastgesteld in Kamerbrieven van toenmalig staatssecretaris Dijksma (Kamerbrieven van resp. 06-12-2013, 06-06-2014 en 29-07-2014). In haar brief aan de Tweede Kamer van 06-12-2013 worden vergroeningsmaatregelen gekoppeld aan de doelstellingen van 'een goede agrobiodiversiteit, milieukwaliteit en bescherming van het klimaat'. In bijlage 1 en 2 wordt verder in meer detail uitgelegd hoe vergroening nationaal is ingevuld voor de drie vergroeningsverplichtingen.

Elk jaar worden ook nog kleine wijzigingen doorgevoerd in het vergroeningsbeleid. In 2020 vonden echter geen wijzigingen plaats, maar de belangrijkste recente wijzigingen werden al in 2019 doorgevoerd. Deze zijn dat er nog drie nieuwe mogelijkheden bijgekomen zijn voor het inzetten van EA met het pakket Algemene Lijst, namelijk:

1. braakliggend land met een mengsel van drachtplanten (planten die gunstig zijn voor bijen);

2. gewassen zonnekroon en olifantsgras;

3. zonnebloem als vanggewas categorie 1 als onderdeel van een mengsel;

4. hybride soorten vanggewassen als onderdeel van een mengsel. Dit moeten wel kruisingen zijn van de soorten uit categorie 1 of 2 .

Ook bij het Akkerbouwstrokenpakket en het Vezelhenneppakket kunnen hybride soorten vanggewassen worden ingezet. Hiervoor gelden dezelfde voorwaarden als bij de Algemene Lijst.

Tot slot zijn de eisen voor de afmetingen van landschapselementen versoepeld sinds 2019. Elementen die iets te groot waren, kunnen nu wel worden aangemerkt als EA en tellen dan mee tot een maximale breedte of oppervlakte. Voor bufferstroken, akkerranden, heggen, houtwallen, bomen in rij, stroken langs bos, boomgroepen en vijvers gelden hiervoor nog wel aanvullende regels in relatie tot hoe ze mogen meetellen. Voor verdere details over invulling van deze veranderingen zie ook bijlage 1 en 2 . 


\subsection{Doelstellingen van vergroening in het GLB en EU- monitoring in het Gemeenschappelijk Toezicht en Evaluatie Kader}

Zoals ook al in voorgaande rapporten aangegeven, heeft de vergroening als belangrijkste doelstelling het verbeteren van de algehele milieuprestatie (environmental performance) van een agrarisch bedrijf, waarbij het specifiek gaat om verbetering van de biodiversiteit, de bodem- en waterkwaliteit en het verminderen van broeikasgassen (EC COM 1307/2013). Bovendien zijn deze milieudoelstellingen specifieker geformuleerd per type vergroeningsmaatregel (zie Kader 1). Zo heeft de invoering van de Ecologische Aandachtsgebieden (EA's) primair als doelstelling het verbeteren van de biodiversiteit, terwijl het in stand houden van blijvend grasland een bredere, algehele milieuprestatie dient, maar ook een specifieke, namelijk het vastleggen van koolstof ten behoeve van het klimaat (zie Kader 1).

Kader 1: Specifieke milieudoelstellingen van vergroeningsmaatregelen (EC COM 1307/2013)

Ecological focus areas 'should be established, in particular, in order to safeguard and improve biodiversity on farms. The ecological focus area should therefore consist of areas directly affecting biodiversity such as land lying fallow, landscape features, terraces, buffer strips, afforested areas and agro-forestry areas, or indirectly affecting biodiversity through a reduced use of inputs on the farm, such as areas covered by catch crops and winter green cover' (Reg. 1307/2013, EC, 2013).

As to permanent grasslands (PGs) the Regulation 1307/2013 specifies that these should be 'maintained for the sake of the environmental benefits of permanent grassland and in particular carbon sequestration'. 'This protection should consist of a ban on ploughing and conversion on the environmentally most sensitive areas in "Natura 2000" areas covered by Directives 92/43/EEC and 2009/147/EC, and of a more general safeguard, based on a ratio of permanent grassland, against conversion to other uses. Member States should be empowered to delineate further environmentally sensitive areas not covered by those Directives. In addition, they should choose at which territorial level the ratio should apply'

(Reg. 1307/2013, EC, 2013).

Voor het meten van resultaten en effecten van invoering van het GLB, is er een Gemeenschappelijk Toezicht en Evaluatie Kader (GTEK) ontwikkeld. Dit GTEK wordt gebruikt om de effecten van GLBmaatregelen zoals in de lidstaten toegepast, te monitoren. Dit GTEK is dus ook van toepassing op vergroening. Invoering van het GTEK is primair gericht op het toetsen van het halen van de GLBdoelstellingen. De vergroeningsmaatregelen zijn met name te koppelen aan de tweede, algemene doelstelling van het GLB en dat is 'duurzaam beheer van natuurlijke hulpbronnen en klimaataanpak'.

In het GTEK worden verschillende typen doelstellingen van het GLB gekoppeld aan verschillende typen indicatoren. Een onderscheid wordt gemaakt in effectindicatoren, resultaatindicatoren en outputindicatoren. Voor vergroening (ingevoerd vanaf januari 2015) zijn aan het GTEK verschillende effect-, resultaat- en outputindicatoren toegevoegd die de voortgang en effecten van dit nieuwe beleid moeten meten (zie Kader 2). 
Kader 2: Drie typen indicatoren in het GTEK

De effectindicatoren meten in hoeverre de algemene doelstellingen van het GLB gehaald worden; in het geval van vergroening gaat het dan om de bijdrage van het GLB aan duurzaam beheer van natuurlijke hulpbronnen en klimaataanpak en specifieke effectindicatoren hiervoor in het GTEK gaan over ontwikkeling in populaties boerenlandvogels, uitstoot van broeikasgassen, waterkwaliteit, organischestofgehalte in de bodem, bodemerosie en areaal boerenland met hoge natuurwaarde (zogenaamde High Nature Value farmland).

Resultaatindicatoren meten de directe effecten van een beleidsmaatregel. Bij vergroening wordt dan met resultaatindicatoren veel meer gemeten wat de directe uitkomsten zijn van de implementatie van de maatregelen. Voorbeelden van dergelijke indicatoren zijn het aandeel landbouwareaal dat onder vergroeningsmaatregelen valt, het aandeel EA in het landbouwareaal en het aandeel blijvend grasland in het totaalareaal.

Outputindicatoren meten de toepassing van maatregelen en instrumenten. Voor vergroening zijn vanaf 2015 verschillende outputindicatoren toegevoegd aan het GTEK die te koppelen zijn aan de separate vergroeningsmaatregelen, namelijk aantal boeren met vergroeningmaatregelen, areaal EA, areaal met gewasdiversificatie en areaal blijvend grasland.

$\mathrm{Na}$ vier jaar vergroening is er al een aantal studies uitgevoerd naar de resultaten van de vergroening voor de gehele EU. De uitkomsten van deze studies worden uitgebreid besproken in Elbersen (et al., 2018).

In dit rapport worden de resultaten van de evaluatie van vergroening voor Nederland over 2020 gepresenteerd en ook vergeleken met resultaten in voorgaande jaren. Tevens zullen de conclusies in hoofdstuk 3 van deze studie, net als in de voorgaande rapportages, ook in het licht worden geplaatst van de uitkomsten van de in Elbersen et al. (2018) reeds besproken uitkomsten van bredere evaluatiestudies van vergroening.

\subsection{Methode voor monitoring van vergroening in Nederlandse situatie}

De hier gepresenteerde studie volgt de methode die door Van Doorn et al. (2015) werd uitgewerkt, zodat de resultaten van deze studie ook met die van voorgaande jaren vergeleken kunnen worden. Hierdoor kan ook een totaaloverzicht gepresenteerd worden in dit rapport van de resultaten van de vergroening over een periode van zes jaar.

Bij de ontwikkeling van het monitoringsraamwerk voor vergroening voor de Nederlandse situatie, hebben Van Doorn et al. (2015) de vergroeningsindicatoren in het GTEK als uitgangspunt genomen. De GTEKindicatoren zijn vervolgens verder uitgewerkt voor de Nederlandse situatie, waarbij rekening is gehouden met de nationale keuzes voor vergroening en de relevantie van vergroening voor Nederland, de kosteneffectiviteit, door zo veel mogelijk gebruik te maken met bestaande gegevensbestanden en de mogelijkheid van gebruik van meer ruimtelijk expliciete data (als die voorhanden zijn).

Het indicatorraamwerk Van Doorn et al. (2015) wordt dus in deze monitoringstudie opnieuw toegepast en een overzicht van de output- en resultaatindicatoren is te vinden in bijlage 3 van dit rapport.

\subsection{Leeswijzer}

In dit eerste hoofdstuk zijn de achtergronden van de studie beschreven, is uitgelegd wat het actuele vergroeningsbeleid in de praktijk inhoudt en met welke systematiek de monitoring en evaluatie van vergroening in de Nederlandse situatie wordt uitgevoerd. In hoofdstuk 2 worden de resultaten van de monitoring en evaluatie van vergroening voor 2020 gepresenteerd en vergeleken met die voor de jaren $2015 \mathrm{t} / \mathrm{m}$ 2019. In hoofdstuk 3 ten slotte staan de belangrijkste conclusies over de trendanalyse 2015-2020 met betrekking tot de resultaten van vergroening. 


\section{Resultaten van de evaluatie en monitoring van vergroening na vier jaar}

\section{$2.1 \quad$ Inleiding}

In dit hoofdstuk worden de resultaten van de monitoring en evaluatie van vergroening voor 2020 gepresenteerd en vergeleken met voorgaande jaren.

Allereerst zal in paragraaf 2.2 een overzicht volgen van deelname aan vergroeningsmaatregelen, equivalente maatregelen en vrijstellingen van vergroening. In paragraaf 2.3 worden beheer van blijvend grasland en toepassing van ploeg- en omzetverbod in blijvende kwetsbare graslandgebieden besproken. Tot slot gaat paragraaf 2.4 over de toepassing van EA's. De vergroeningsmaatregelen worden in dit hoofdstuk allemaal gemonitord op basis van de indicatoren zoals door Van Doorn et al. (2015) ontwikkeld (zie bijlage 3).

\subsection{Algemeen, gewasdiversificatie en equivalente maatregelen}

Over de onderzoeksperiode $2015-2020$ is het totaalaantal landbouwbedrijven met bijna $18 \%$ gedaald, van 63910 naar 52695 (tabel 2). Deze daling was veruit het grootst tussen 2015 en 2016 . Het areaal landbouwgrond nam in dezelfde periode echter met slechts $2 \%$ af. Het totaalaantal landbouwbedrijven daalt sneller dan het aantal dat zich aan ten minste één vergroeningsmaatregel moet houden. Dit betekent ook dat het aantal landbouwbedrijven dat zich hieraan moet houden relatief is toegenomen: van $78 \%$ in 2015 naar $83 \%$ in 2020 (tabel 2). Overigens is dit percentage tussen 2018 en 2020 redelijk stabiel gebleven. Het percentage landbouwgrond dat ten minste onder één vergroeningsverplichting valt, is eerst gestegen van $96 \%$ naar $98 \%$ en bevindt zich de laatste twee jaren op $97 \%$.

In areaal heeft de vergroening een relatief grote reikwijdte (van 92\% van totale oppervlakte landbouwgrond in Nederland in 2020). Echter, dit getal moet om twee redenen voorzichtig worden geïnterpreteerd. Ten eerste omdat $77 \%$ van dit vergroeningsareaal bij bedrijven hoort die zich aan de instandhouding van blijvend grasland moeten houden. Omdat het blijvend graslandareaal niet is gedaald t.o.v. het referentieratio blijvend grasland (zie tabel 4), hoeven boeren met blijvend grasland geen enkele concrete actie te ondernemen om zich aan de vergroeningsverplichting te houden. Ten tweede omdat op slechts een beperkt deel van dit vergroeningsareaal sprake is van verandering in landbouwpraktijk, zoals zal blijken uit de gedetailleerde analyse van de EA-gebiedenverplichting in paragraaf 2.4 .

Wel kan men concluderen dat Nederland een relatief groot areaal heeft dat onder vergroening valt. In Nederland ligt dit in de laatste jaren stabiel op 92\%. Wat het EU-gemiddelde in 2020 is, is niet bekend, maar in 2017 lag het gemiddelde op 73\% van het landbouwareaal (Europese Rekenkamer, 2017).

De relatieve en absolute stijging in vergroeningsareaal tussen 2015 en 2020 zijn overigens wel voornamelijk veroorzaakt door bedrijven die zich aan de instandhouding blijvend grasland moeten houden. Opvallend is dat tussen 2015 en 2020 het landbouwareaal behorend bij deze bedrijven is toegenomen met $7 \%$, terwijl het totaal landbouwareaal behorende bij bedrijven met ten minste één vergroeningsverplichting in dezelfde periode slechts met $1 \%$ toenam (zie tabel 2 ). De toename in blijvend graslandareaal hangt niet met vergroening samen, maar zeer waarschijnlijk met de aangescherpte mestnormen in de landbouw. 
Tabel 2 Overzicht van outputindicatoren van alle vergroeningsmaatregelen 2015-2020.

\begin{tabular}{|c|c|c|c|c|c|c|c|c|}
\hline & & Jaar & Aantal boeren & $\% *$ & $\begin{array}{r}\text { Opp. } \\
\text { landbouwgrond (ha) }\end{array}$ & $\% *$ & $\begin{array}{r}\text { Opp. } \\
\text { Bouwland (ha) }\end{array}$ & $\begin{array}{l}\text { Opp. blijvend } \\
\text { grassland (ha) }\end{array}$ \\
\hline \multirow{12}{*}{ Totaal } & \multirow{6}{*}{ Totaalaantal boeren in Nederland } & 2015 & 63910 & $100 \%$ & 1845750 & $100 \%$ & 1070510 & 714340 \\
\hline & & 2016 & 55364 & $100 \%$ & 1792219 & $100 \%$ & 1057098 & 689935 \\
\hline & & 2017 & 55645 & $100 \%$ & 1811571 & $100 \%$ & 1065533 & 783461 \\
\hline & & 2018 & 53780 & $100 \%$ & 1811048 & $100 \%$ & 1049595 & 779136 \\
\hline & & 2019 & 53230 & $100 \%$ & 1816320 & $100 \%$ & 1039084 & 767542 \\
\hline & & 2020 & 52695 & $100 \%$ & 1814450 & $100 \%$ & 1031962 & 772411 \\
\hline & \multirow{6}{*}{$\begin{array}{l}\text { Aantal boeren met aangevraagde } \\
\text { betalingsrechten }\end{array}$} & 2015 & 49941 & $78 \%$ & 1766145 & $96 \%$ & 1005320 & 722991 \\
\hline & & 2016 & 45750 & $83 \%$ & 1749722 & $98 \%$ & 975586 & 737963 \\
\hline & & 2017 & 45069 & $81 \%$ & 1765973 & $97 \%$ & 972708 & 753614 \\
\hline & & 2018 & 44758 & $83 \%$ & 1771113 & $98 \%$ & 979366 & 752958 \\
\hline & & 2019 & 44244 & $83 \%$ & 1764027 & $97 \%$ & 977602 & 748747 \\
\hline & & 2020 & 43803 & $83 \%$ & 1764633 & $97 \%$ & 970043 & 757099 \\
\hline \multirow{19}{*}{ Vergroening } & \multirow{6}{*}{$\begin{array}{l}\text { Aantal boeren dat ten minste één } \\
\text { vergroeningsverplichting heeft }\end{array}$} & 2015 & 42802 & $67 \%$ & 1659049 & $90 \%$ & 934,864 & 709117 \\
\hline & & 2016 & 40503 & $70 \%$ & 1661010 & $93 \%$ & 934,885 & 710629 \\
\hline & & 2017 & 40435 & $73 \%$ & 1669002 & $92 \%$ & 929022 & 722204 \\
\hline & & 2018 & 39782 & $74 \%$ & 1669749 & $92 \%$ & 933815 & 719374 \\
\hline & & 2019 & 39384 & $74 \%$ & 1673832 & $92 \%$ & 934746 & 722816 \\
\hline & & 2020 & 38984 & $74 \%$ & 1670349 & $92 \%$ & 925671 & 728061 \\
\hline & \multirow{6}{*}{$\begin{array}{l}\text { Aantal boeren dat zich aan } \\
\text { gewasdiversificatie moet houden }\end{array}$} & 2015 & 13884 & $22 \%$ & 720068 & $39 \%$ & 658073 & - \\
\hline & & 2016 & 13092 & $24 \%$ & 696826 & $39 \%$ & 634298 & - \\
\hline & & 2017 & 13125 & $24 \%$ & 709470 & $39 \%$ & 644986 & - \\
\hline & & 2018 & 12965 & $24 \%$ & 705569 & $39 \%$ & 646625 & - \\
\hline & & 2019 & 12888 & $24 \%$ & 705956 & $39 \%$ & 648878 & - \\
\hline & & 2020 & 12802 & $24 \%$ & 708950 & $39 \%$ & 647801 & - \\
\hline & \multirow{7}{*}{$\begin{array}{l}\text { Aantal boeren dat zich aan EA-maatregel } \\
\text { moet houden }\end{array}$} & 2015 & 11430 & $18 \%$ & 679705 & $37 \%$ & 626250 & - \\
\hline & & 2016 & 10655 & $19 \%$ & 635965 & $35 \%$ & 582736 & - \\
\hline & & 2017 & 10585 & $19 \%$ & 644648 & $36 \%$ & 589209 & - \\
\hline & & 2018 & 10799 & $20 \%$ & 658139 & $36 \%$ & 607948 & - \\
\hline & & 2019 & 10772 & $20 \%$ & 661178 & $36 \%$ & 612521 & - \\
\hline & & 2020 & 10839 & $21 \%$ & 675473 & $37 \%$ & 623247 & - \\
\hline & & 2015 & 35646 & $56 \%$ & 1295315 & $70 \%$ & - & 708563 \\
\hline
\end{tabular}




\begin{tabular}{|c|c|c|c|c|c|c|c|c|}
\hline & & Jaar & Aantal boeren & $\% *$ & $\begin{array}{r}\text { Opp. } \\
\text { landbouwgrond (ha) }\end{array}$ & $\% *$ & $\begin{array}{r}\text { Opp. } \\
\text { Bouwland (ha) }\end{array}$ & $\begin{array}{l}\text { Opp. blijvend } \\
\text { grassland (ha) }\end{array}$ \\
\hline & \multirow{5}{*}{$\begin{array}{l}\text { Aantal boeren dat zich aan blijvend } \\
\text { graslandverplichting moet houden }\end{array}$} & 2016 & 33186 & $60 \%$ & 1303595 & $73 \%$ & - & 690270 \\
\hline & & 2017 & 33434 & $60 \%$ & 1325144 & $73 \%$ & - & 687299 \\
\hline & & 2018 & 33467 & $62 \%$ & 1355454 & $75 \%$ & - & 708783 \\
\hline & & 2019 & 33480 & $63 \%$ & 1374064 & $76 \%$ & - & 716466 \\
\hline & & 2020 & 33363 & $63 \%$ & 1388415 & $77 \%$ & - & 717536 \\
\hline \multirow{12}{*}{ Vrijstelling } & \multirow{6}{*}{$\begin{array}{l}\text { Aantal boeren dat vrijgesteld is van } \\
\text { vergroening: biologische bedrijven }\end{array}$} & 2015 & 1148 & $2 \%$ & 46483 & $3 \%$ & 20328 & 25627 \\
\hline & & 2016 & 1157 & $2 \%$ & 57580 & $3 \%$ & 30068 & 27334 \\
\hline & & 2017 & 1281 & $2 \%$ & 58834 & $3 \%$ & 23058 & 35400 \\
\hline & & 2018 & 1355 & $3 \%$ & 61969 & $3 \%$ & 24614 & 36971 \\
\hline & & 2019 & 1167 & $2 \%$ & 55353 & $3 \%$ & 23515 & 31399 \\
\hline & & 2020 & 1248 & $2 \%$ & 60688 & $3 \%$ & 26072 & 34085 \\
\hline & \multirow{6}{*}{$\begin{array}{l}\text { Aantal boeren dat vrijgesteld is van } \\
\text { gewasdiversificatie en niet verplicht is } \\
\text { voor EA-maatregel }\end{array}$} & 2015 & 38684 & $61 \%$ & 1086497 & $59 \%$ & 379236 & 676187 \\
\hline & & 2016 & 34009 & $61 \%$ & 1077934 & $60 \%$ & 369981 & 690146 \\
\hline & & 2017 & 34165 & $61 \%$ & 1080109 & $60 \%$ & 356098 & 704631 \\
\hline & & 2018 & 33580 & $62 \%$ & 1053056 & $58 \%$ & 332740 & 702827 \\
\hline & & 2019 & 31874 & $60 \%$ & 1027975 & $57 \%$ & 332924 & 675701 \\
\hline & & 2020 & 31314 & $59 \%$ & 1019609 & $56 \%$ & 332924 & 677645 \\
\hline \multirow{16}{*}{ Equivalente maatregelen } & \multirow{6}{*}{$\begin{array}{l}\text { Totaalaantal boeren dat equivalente } \\
\text { maatregelen opgeeft }\end{array}$} & 2015 & 320 & $1 \%$ & 29230 & $2 \%$ & 28400 & 771 \\
\hline & & 2016 & 322 & $1 \%$ & 29847 & $2 \%$ & 29076 & 729 \\
\hline & & 2017 & 341 & $1 \%$ & 29450 & $2 \%$ & 28216 & 1171 \\
\hline & & 2018 & 205 & $0 \%$ & 19819 & $1 \%$ & 19018 & 762 \\
\hline & & 2019 & 166 & $0 \%$ & 17124 & $1 \%$ & 16544 & 559 \\
\hline & & 2020 & 90 & $0 \%$ & 8262 & $0 \%$ & 7917 & 347 \\
\hline & \multirow{6}{*}{$\begin{array}{l}\text { Aantal boeren dat equivalente } \\
\text { maatregelen opgeeft: Akkerranden-pakket }\end{array}$} & 2015 & 82 & $0 \%$ & 4851 & $0 \%$ & 4489 & 335 \\
\hline & & 2016 & 62 & $0 \%$ & 3241 & $0 \%$ & 2997 & 249 \\
\hline & & 2017 & 110 & $0 \%$ & 4722 & $0 \%$ & 4050 & 632 \\
\hline & & 2018 & 72 & $0 \%$ & 3609 & $0 \%$ & 3255 & 311 \\
\hline & & 2019 & 41 & $0 \%$ & 1927 & $0 \%$ & 1805 & 125 \\
\hline & & 2020 & 39 & $0 \%$ & 1818 & $0 \%$ & 1742 & 83 \\
\hline & \multirow{4}{*}{$\begin{array}{l}\text { Aantal boeren dat equivalente } \\
\text { maatregelen opgeeft: Veldleeuwerik- } \\
\text { pakket }\end{array}$} & 2015 & 238 & $1 \%$ & 24380 & $1 \%$ & 23911 & 436 \\
\hline & & 2016 & 212 & $1 \%$ & 22073 & $1 \%$ & 21622 & 404 \\
\hline & & 2017 & 170 & $1 \%$ & 17716 & $1 \%$ & 17293 & 408 \\
\hline & & 2018 & 70 & $0 \%$ & 8709 & $0 \%$ & 8464 & 251 \\
\hline
\end{tabular}




\begin{tabular}{|c|c|c|c|c|c|c|c|c|}
\hline & & Jaar & Aantal boeren & $\% *$ & $\begin{array}{r}\text { Opp. } \\
\text { landbouwgrond (ha) }\end{array}$ & $\% *$ & $\begin{array}{r}\text { Opp. } \\
\text { Bouwland (ha) }\end{array}$ & $\begin{array}{l}\text { Opp. blijvend } \\
\text { grassland (ha) }\end{array}$ \\
\hline & & 2019 & 68 & $0 \%$ & 8662 & $0 \%$ & 8427 & 216 \\
\hline & & 2020 & 0 & $0 \%$ & 0 & $0 \%$ & 0 & 0 \\
\hline & & 2015 & - & - & & - & & \\
\hline & & 2016 & 48 & $0 \%$ & 4533 & $0 \%$ & 4456 & 76 \\
\hline & Aantal boeren dat equivalente & 2017 & 61 & $0 \%$ & 7011 & $0 \%$ & 6873 & 131 \\
\hline & maatregelen opgeeft: Vezelhennep-pakket & 2018 & 63 & $0 \%$ & 7502 & $0 \%$ & 7298 & 200 \\
\hline & & 2019 & 57 & $0 \%$ & 6534 & $0 \%$ & 6313 & 218 \\
\hline & & 2020 & 51 & & 6444 & & 6175 & 264 \\
\hline \multirow{12}{*}{ Gewasdiversificatie } & \multirow{6}{*}{$\begin{array}{l}\text { Aantal boeren dat zich aan } \\
\text { gewasdiversificatie met twee gewassen } \\
\text { moet houden }\end{array}$} & 2015 & 6573 & $10 \%$ & 145372 & $8 \%$ & 121970 & - \\
\hline & & 2016 & 6014 & $10 \%$ & 134121 & $7 \%$ & 111360 & - \\
\hline & & 2017 & 5978 & $11 \%$ & 134725 & $7 \%$ & 111542 & - \\
\hline & & 2018 & 5877 & $11 \%$ & 133828 & $7 \%$ & 110269 & - \\
\hline & & 2019 & 5821 & $11 \%$ & 131428 & $7 \%$ & 109127 & - \\
\hline & & 2020 & 5829 & $11 \%$ & 133714 & $7 \%$ & 109705 & - \\
\hline & \multirow{6}{*}{$\begin{array}{l}\text { Aantal boeren dat zich aan } \\
\text { gewasdiversificatie met drie gewassen } \\
\text { moet houden }\end{array}$} & 2015 & 7311 & $11 \%$ & 574695 & $32 \%$ & 536104 & - \\
\hline & & 2016 & 7078 & $12 \%$ & 562705 & $32 \%$ & 522939 & - \\
\hline & & 2017 & 7147 & $13 \%$ & 574745 & $32 \%$ & 533444 & - \\
\hline & & 2018 & 7088 & $13 \%$ & 571740 & $32 \%$ & 536356 & - \\
\hline & & 2019 & 7067 & $13 \%$ & 574528 & $32 \%$ & 539751 & - \\
\hline & & 2020 & 6973 & $13 \%$ & 575236 & $32 \%$ & 538096 & - \\
\hline
\end{tabular}

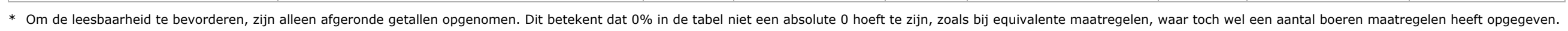
Hun aantal en areaal blijft echter ruim onder de $0,5 \%$ van het totaalaantal boeren en landbouwareaal. 
Het percentage boeren dat zich aan gewasdiversificatie moet houden, is alleen tussen 2015 en 2016 gestegen en is daarna gestabiliseerd tot 24\%; dit heeft betrekking op $39 \%$ van de landbouwgrond. Dit ging tot 2019 gepaard met een lichte daling in het bijbehorende landbouwareaal, maar lijkt naar 2020 juist weer wat toe te nemen (zie tabel 2).

De gewasdiversificatieverplichting zal overigens in de praktijk weinig inspanning vergen van boeren, aangezien de maatregel vrijwel niets toevoegt aan de gangbare landbouwpraktijk (Van Doorn \& Smidt, 2017; Europese Rekenkamer, 2017; Louhichi et al., 2017).

Wat betreft equivalente maatregelen kunnen sinds 2020 slechts twee soorten pakketten worden opgegeven, want het Veldleeuwerikpakket is komen te vervallen. In 2018 namen in totaal 205 boeren deel aan equivalente maatregelen. In 2019 is dit aantal gedaald naar 166 en dit daalt verder naar 90 in 2020. Deze daling zit voornamelijk in de afschaffing van het Veldleeuwerikpakket. Voor de afschaffing van dit pakket was er al een sterke afname te zien bij boeren die voor dit pakket kozen door een wijziging van de voorwaarden in de standaardsituatie (voorwaarden buiten de equivalente praktijken). Hierdoor was het verschil met het equivalente pakket Veldleeuwerik kleiner. De instandhoudingstermijn van de standaard vergroeningsmaatregel EA-vanggewassen is door de EU in 2018 verkort van tien naar acht weken. Omdat hiermee de geboden keuze binnen het Veldleeuwerikpakket feitelijk een lege huls werd, is bij het equivalente pakket Veldleeuwerik de instandhoudingstermijn vervolgens ook op acht weken gesteld. Hierdoor bestaat er geen verschil meer met de standaardsituatie EA-vanggewas. Dit is naar alle waarschijnlijkheid de reden dat minder landbouwers van het equivalente pakket Veldleeuwerik gebruik gingen maken vanaf 2018, naar zelfs volledige afschaffing in 2020. Overigens is door de bijstelling van de standaardsituatie ook de interesse bij boeren voor de andere equivalente maatregelen, het Akkerrandenpakket en het Vezelhenneppakket, verder afgenomen in 2020.

\subsection{Instandhouding blijvend grasland}

In Nederland wordt blijvend grasland op nationaal niveau gemonitord. Dit betekent dat het blijvend grasland (BG) areaal in Nederland ten opzichte van het referentiejaar 2012 met niet meer dan 5\% mag afnemen. Het gaat hierbij om het relatieve graslandareaal als percentage van het totale landbouwareaal. RVO monitort dit aandeel jaarlijks en heeft berekend dat het percentage voor het referentiejaar 2012 40,97\% bedraagt. Na een daling in de jaren 2015 tot en met 2017 ten opzichte van het referentiejaar, is er vanaf 2018 weer een stijging ingezet en die gaat ook in 2020 door (tabel 3). Zoals al eerder opgemerkt, hangt deze stijging niet met vergroening samen, maar met de aanpassing van de mestnormen, wat bij veel boeren heeft geleid tot uitbreiding van het blijvend graslandareaal in de laatste jaren. ${ }^{2}$

Tabel 3 Het aandeel blijvend grasland binnen het totaal landbouwareaal ten opzichte van het referentiejaar 2012.

\begin{tabular}{lll} 
Referentieratio & 40,97 & Verandering t.0.V. referentieratio \\
\hline Aandeel 2015 & 40,59 & $-0,91 \%$ \\
\hline Aandeel 2016 & 40,56 & $-0,99 \%$ \\
\hline Aandeel 2017 & 40,15 & $-2,01 \%$ \\
\hline Aandeel 2018 & 41,26 & $+0,71 \%$ \\
\hline Aandeel 2019 & 41,68 & $+1,74 \%$ \\
\hline Aandeel 2020 & 41,91 & $+2,29 \%$ \\
\hline
\end{tabular}

\footnotetext{
2 De fosfaatgebruiksruimte op gras ligt hoger dan op bouwland. Ook voor derogatieaanvraag in 2020 geldt weer dat er een minimumareaal van $80 \%$ grasland op het bedrijf verplicht is (ingevoerd sinds 2015). Nieuw in 2020 is dat bij scheuren of vernietigen (omploegen) van grasland een korting op de stikstofgebruikersnorm toegepast wordt op dat perceel. Zie: https://www.rvo.nl/sites/default/files/2019/11/Hoeveel\%20mest\%20uitrijden\%20hoe\%20rekent\%20u\%20dat\%20uit\%2 028-11-19\%20v1.pdf
} 
Tabel 4 Overzicht van output indicatoren voor vergroening met blijvend grasland (BG) en Ecologisch Kwetsbaar Blijvend Grasland (EKBG) maatregelen.

\begin{tabular}{|c|c|c|c|c|c|c|c|}
\hline & Jaar & $\begin{array}{l}\text { Aantal } \\
\text { boeren }\end{array}$ & $\begin{array}{r}\% \text { van } \\
\text { alle } \\
\text { boeren }\end{array}$ & $\begin{array}{r}\text { Opp. } \\
\text { landbouw- } \\
\text { grond (ha) }\end{array}$ & $\begin{array}{r}\% \text { van } \\
\text { landbouw- } \\
\text { grond }\end{array}$ & $\begin{array}{r}\text { Opp. bl. } \\
\text { grasland (ha) }\end{array}$ & $\begin{array}{r}\% \mathrm{bl} . \\
\text { grasland }\end{array}$ \\
\hline \multirow{4}{*}{$\begin{array}{l}\text { Aantal boeren met blijvend } \\
\text { grasland }\end{array}$} & 2016 & 33186 & $60 \%$ & 1303595 & $73 \%$ & 690270 & \\
\hline & 2017 & 33434 & $60 \%$ & 1325144 & $73 \%$ & 687299 & \\
\hline & 2019 & 33480 & $63 \%$ & 1374064 & $76 \%$ & 716466 & \\
\hline & 2020 & 33363 & $63 \%$ & 1388415 & $77 \%$ & 717536 & \\
\hline \multirow{4}{*}{$\begin{array}{l}\text { Aangewezen ha Ecologisch } \\
\text { Kwetsbaar Blijvend Grasland } \\
\text { EKBG (in N2000)* }\end{array}$} & 2015 & & & & & 49932 & $7 \%$ \\
\hline & 2016 & & & & & 50815 & $7 \%$ \\
\hline & 2017 & & & & & 57996 & $8 \%$ \\
\hline & 2020 & & & & & 59804 & $8 \%$ \\
\hline \multirow{6}{*}{$\begin{array}{l}\text { Aantal boeren met EKBG (in } \\
\text { N2000)** }\end{array}$} & 2015 & 3387 & $5 \%$ & 174448 & $9 \%$ & 37588 & $5 \%$ \\
\hline & 2016 & 3237 & $6 \%$ & 173235 & $10 \%$ & 36002 & $5 \%$ \\
\hline & 2017 & 3291 & $6 \%$ & 182165 & $10 \%$ & 36979 & $5 \%$ \\
\hline & 2018 & 3293 & $6 \%$ & 191416 & $11 \%$ & 42428 & $6 \%$ \\
\hline & 2019 & 3264 & $6 \%$ & 192770 & $11 \%$ & 41365 & $5 \%$ \\
\hline & 2020 & 3258 & $6 \%$ & 194999 & $11 \%$ & 41677 & $5 \%$ \\
\hline
\end{tabular}

* Inclusief blijvend grasland bij niet-directe betaling aanvragers en blijvend grasland bij boeren vrijgesteld van betalingen en grasland met als hoofdfunctie natuur.

** Exclusief grasland van boeren die zijn vrijgesteld van vergroening en grasland met als hoofdfunctie natuur.

Voor de vergroening zijn alle bedrijven met blijvend grasland automatisch vergroeningsplichtig, echter zolang de daling van het relatieve areaal niet meer dan $5 \%$ bedraagt, hoeft de ruime meerderheid van de boerenbedrijven met blijvend grasland (63\% van alle landbouwbedrijven dat $93 \%$ van het totale blijvend grasland beheert) hier niets voor te doen. Ploegen en scheuren en omzetten op dit grasland mag. Het aandeel landbouwbedrijven met blijvend grasland is tussen 2015 en 2020 relatief toegenomen, van 56\% naar 63\%. Deze stijging ten opzichte van 2015 gaat gepaard met een kleine jaarlijkse toename in het areaal blijvend grasland (zie tabel 4), die ook naar 2020 weer doorzette. Deze lichte stijging is in 2018 in gang gezet, terwijl in de jaren ervoor juist sprake was van een daling (zie tabel 4 en kader 2). Het CBS $^{4}$ geeft aan dat deze stijging in blijvend grasland vooral in ZuidNederland plaatsheeft gehad. Redenen voor deze toename hangen samen met afschaffing van het melkquotum in 2015, waardoor de melkveestapel en daarmee samenhangend het blijvend grasland areaal gingen stijgen. Tevens zijn de voorwaarden voor verhoogde mestnormen (derogatie) gewijzigd, waardoor bepaalde bedrijven gestimuleerd werden om een bepaald percentage grasland aan te houden.

Voor 6\% van de boeren in 2020 (5\% in 2015) geldt een ploeg- en omzetverbod, omdat zij graslanden binnen Natura 2000-gebieden beheren en deze graslanden zijn aangewezen als Ecologisch Kwetsbaar blijvend grasland (EKBG). Hun aantal is praktisch gelijk gebleven, maar het areaal landbouwgrond en blijvend grasland dat bij deze bedrijven hoort, is wel gestegen tussen 2019 en 2020. Of dit een stijging betreft in door boeren beheerd EKBG-grasland is niet volledig vast te stellen, omdat het blijvend graslandareaal gerapporteerd in tabel 4 van boeren met EKGB zowel binnen als buiten Natura 2000-gebieden kan liggen. Echter het totaalareaal aangewezen EKGB is tussen 2019 en 2020 licht gedaald. Het vermoeden is daarom dat de stijging in blijvend grasland op de bedrijven juist buiten Natura-2000 plaats heeft gehad en dus niet EKBG betreft.

Nederland heeft ervoor gekozen $100 \%$ van al het blijvend grasland binnen Natura 2000 -gebieden als kwetsbaar aan te wijzen. Dit komt overeen met een oppervlakte van 59804 ha, wat overeenkomt met $8 \%$ van het totale blijvend graslandareaal in 2020 (zie tabel 4). Echter niet al deze hectaren kwetsbaar blijvend grasland vallen onder de vergroeningsverplichting. Zo behoort circa 582 ha van 
deze graslanden bij biologische bedrijven en die zijn per definitie groen. ${ }^{3}$ Circa 5150 ha heeft de functie natuur (i.p.v. landbouw). ${ }^{4}$ De rest is niet opgegeven in gecombineerde opgave. Hierdoor geldt ook voor dit deel van het blijvend grasland geen vergroeningsverplichting. Dit verklaart waarom slechts een deel van het totaal aangewezen areaal kwetsbaar blijvend grasland (EKBG) ook blijvend grasland is met een vergroeningsverplichting (tabel 4 ).

Het omzetverbod voor blijvend grasland wordt daarmee op 41677 ha door de maatregel vergroening gehandhaafd. Tussen 2015 en 2018 is het areaal EKBG met 12\% toegenomen, waarna een lichte daling in deze toename inzette (tabel 4). In 2020 is er sprake van een toename van $11 \%$ ten opzichte van 2015. De toename in areaal EKBG kan vooral worden verklaard door het in 2018 toestaan in de basisbetalingsregeling van zogenaamde IMNA-gronden. ${ }^{5}$ Hierdoor konden deze gronden worden opgegeven voor uitbetaling van betalingsrechten. Overigens vertoont het aantal boeren dat EKBG opgeeft ook naar 2020 weer een lichte daling. Tegelijkertijd is er dus wel een toename gezien in hectaren kwetsbaar blijvend grasland die niet onder de vergroeningsverplichting valt, namelijk via een stijging van het areaal EKBG dat als data biologisch is aan te merken (zie noot 4) en in EKBG met de functie natuur (zie noot 5 ).

In kader 2 wordt de trend in blijvend graslandareaal in Nederland over de periode 2005-2020 toegelicht. Er is sprake van een daling, met name tussen 2011 en 2015. Deze komt echter niet tot uiting in de trend waarop blijvend grasland gemonitord wordt voor het vergroeningsbeleid. Dit komt omdat het een relatieve trend betreft, die gebaseerd is op de verandering van het relatieve percentage blijvend grasland ten opzichte van het totale landbouwareaal conform Europese regelgeving. En aangezien ook het totale landbouwareaal sterker is gedaald in deze periode, is de relatieve daling van blijvend grasland zodoende ook veel minder. In de laatste twee jaar neemt het areaal BG duidelijk toe, nadat in 2018 al een lichte stijging zichtbaar werd.

In Van Doorn en Smidt (2017) voor de monitoring van vergroening 2016 is ook gekeken naar waar de EKBG vooral liggen (zie Van Doorn en Smidt, 2017; pag. 11, figuur 2). Deze analyse is voor dit rapport niet opnieuw gemaakt, aangezien hierin tussen 2016 en 2020 nauwelijks verandering verwacht kan worden. Voor 2016 is gebleken dat de aangewezen blijvende graslanden in kwetsbare gebieden vooral liggen in de uiterwaarden langs de grote rivieren en op verspreide plekken in de veenweidegebieden van Noord-Holland, het Groene Hart en Arkenheem. Ook werd in Van Doorn en Smidt (2017) op de kaart de ligging van de aangewezen EKBG vergeleken met de ligging van overig waardevol grasland, zoals grasland dat belangrijk is voor weidevogels en gekenmerkt wordt door hoge natuurwaarden: de zogenaamde High Nature Value farmlands (uit Van Doorn et al., 2015). Gebleken is dat de grote meerderheid van deze overige waardevolle blijvende graslanden buiten Natura 2000areaal en dus buiten het aangewezen EKBG-areaal valt.

\footnotetext{
3 Overigens is dit areaal biologisch EKBG tussen 2019 en 2020 gestegen met 476 ha.

4 In dit getal is ook een stijging van 277 ha te zien tussen 2019 en 2020

5 Het betreft percelen waaraan in 2015, 2016 of 2017 geen betalingsrechten zijn toegekend, omdat deze als nietsubsidiabele natuurgronden werden beschouwd. Na uitspraak van het College van Beroep voor het bedrijfsleven (CBb) van 11 juli 2017, zijn deze percelen opnieuw beoordeeld. Een deel van deze percelen is alsnog als subsidiabele landbouwgrond in het perceelsregister opgenomen.
} 
Kader 3: Ontwikkeling in blijvend grasland in Nederland 2005-2020

Over een langere periode bekeken, fluctueert het areaal blijvend grasland en is er tussen 2005 en 2020 sprake van een absolute daling zoals uit de cijfers van RVO blijkt (zie figuur 1). Tussen 2005 en 2020 is het totale blijvend graslandareaal afgenomen van 792014 tot 751169 ha (zie figuur 1). ${ }^{6}$ Tussen 2011 en 2015 is deze afnemende trend sterk, terwijl daarvoor ook sprake was van een lichte stijging. De trend waarop gemonitord wordt en die gebaseerd is op de verandering van het relatieve percentage blijvend grasland ten opzichte van het totale landbouwareaal, is veel kleiner. Dit komt omdat niet alleen het blijvend graslandareaal is gedaald, maar ook het landbouwareaal (van 1951645 ha in 2005 naar 1773183 ha in 2020). De opgaande trend in blijvend grasland die in 2018 begon, lijkt zich door te zetten in $2020 .^{7}$

\section{Blijvend grasland (ha)}

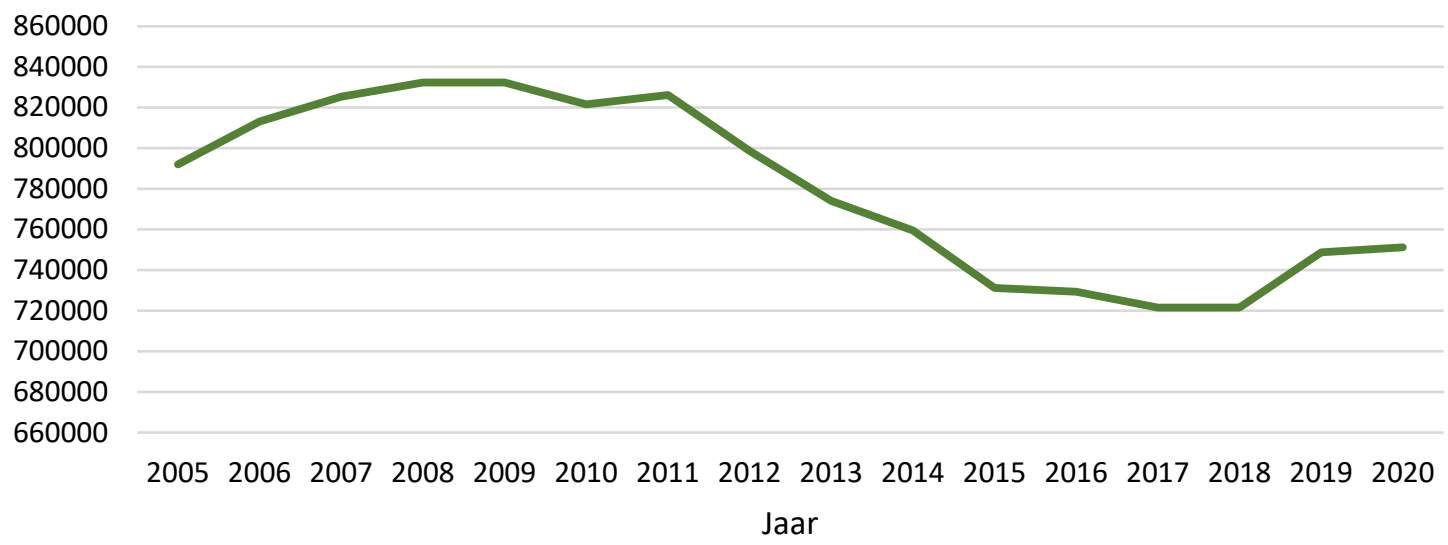

Figuur 1 Ontwikkeling in areaal (absoluut in hectaren) blijvend grasland 2000-2019 (Bron: Gerapporteerde cijfers van RVO, 1 juni 2020).

\section{$2.4 \quad$ Ecologische aandachtsgebieden (EA)}

Een overzicht van de outputindicatoren over de invulling van EA staat in tabel 5 . Uit de tabel blijkt dat het aantal boerenbedrijven met EA-verplichting is afgenomen van 11430 in 2015 naar 10839 in 2020. Deze boerenbedrijven beheren ongeveer 37\% van het totale landbouwareaal in 2020 in Nederland, nog steeds een daling ten opzichte van 2015, maar een stijging ten opzichte van 2018 en deze stijging zet ook door naar 2020.

Het aantal boeren dat voor een collectieve invulling ${ }^{8}$ van EA kiest, is praktisch nihil, met 12 boeren in 2015 naar 2 in 2020.

Op de bedrijven met EA-verplichting bedroeg de omvang EA zonder weging in $201526 \%$ van het bouwlandareaal en dit is toegenomen naar 36\% in 2019 en ook in 2020. Deze relatieve toename hangt samen met het feit dat er richting 2017 een verschuiving heeft plaatsgevonden, waarbij boeren nog iets meer EA's zijn gaan invullen met vanggewassen en stikstofbindende gewassen en nog minder met akkerranden en andere landschapselementen. Deze stijging heeft zich tussen 2019 en 2020 ook verder doorgezet.

${ }^{6}$ Deze cijfers verschillen van die in tabel 3 en 4, omdat dit totaal blijvend graslandareaal betreft, inclusief graslanden met als hoofdfunctie natuur.

7 Het CBS gaf aan dat de toenamen in blijvend grasland vooral in Zuid-Nederland, Brabant en Limburg plaatsvindt. Hier is meer tijdelijk grasland omgezet naar blijvend grasland.

Zie https://www.cbs.nl/nl-nl/nieuws/2016/21/voor-het-eerst-in-9-jaar-meer-blijvend-

grasland\# : :text=De\%20oppervlakte\%20blijvend\%20grasland\%20is, naar\%20ruim\%20714\%20duizend\%20hectare.\&tex $\mathrm{t}=$ De\%20stijging\%20van\%20het\%20areaal, procent\%20en\%2030\%20procent\%20toe.

8 Hierbij werkt een boer samen met andere landbouwers aan een ecologisch aandachtsgebied. Hiervoor moet een collectieve overeenkomst zijn afgesloten. Het EA kan dan buiten de landbouwgrond van een boer vallen, maar wel binnen het areaal dat bij het collectief hoort. 
De vanggewassen hebben een wegingsfactor van 0,3, dus elke hectare vanggewassen telt maar voor 0,3 ha mee als EA (zie bijlage 2). Dit verklaart ook de absolute toename in het EA-areaal. Na toepassing van de wegingsfactoren bedraagt het percentage gewogen areaal EA van het totale bouwlandareaal tussen de $8-11 \%$ in de zes jaren. Dit is ruim boven de norm van $5 \%$ dat elk land verplicht is in te vullen met EA.

Uit de laatste kolom in tabel 5 blijkt dat in Nederland EA-areaal voor 99\% wordt ingevuld door de productiegerelateerde EA's en dat landschapselementen vrijwel niet gekozen worden, tenzij ze onder equivalente pakketten vallen. De belangrijkste soorten vanggewassen die gekozen worden, zijn bladrammenas, gele mosterd, Italiaans en Engels raaigras, Japanse haver en tijdelijk gras. Deze mix verandert weinig tussen de verschillende jaren.

De teelt van vanggewassen na of onder het hoofdgewas heeft in potentie verschillende voordelen voor de bodem: het zorgt voor een toename in het organischestofgehalte in de bodem, er spoelen minder nutriënten uit en deze komen ook geleidelijker beschikbaar erna. Er hoeft vervolgens minder (kunst)mest gebruikt te worden, de bodemstructuur verbetert, het heeft een positieve invloed op het bodemleven en het gaat erosie tegen. Echter omdat het vanggewas slechts kort op het land staat, is de werkelijke bijdrage toch nog vrij onbekend en moet deze verder worden onderzocht. Bovendien dragen vanggewassen - en ook stikstofbindende gewassen - niet of nauwelijks bij aan het verbeteren van de leefruimte van flora en fauna. De ecologische meerwaarde van deze gewassen is dan ook zeer gering, zeker in vergelijking met de niet-productiegebonden EA's als akkerranden, landschapselementen en groene braak. Er kan dan ook geconcludeerd worden dat de inrichting van EA-gebied in Nederland niet bijdraagt aan de doelstelling die verbonden is aan deze maatregelen, namelijk meer ruimte bieden voor biodiversiteit in bouwlandgebieden. Wel kan men constateren dat sinds landschapselementen onderdeel zijn geworden van het EA-pakket in 2016, er een stijging is in het aantal boeren dat voor landschapselementen kiest en dat deze stijging zich ook in 2020 heeft doorgezet (zie tabel 5). Het aantal boeren dat koos voor akkerranden neemt in 2020 weer toe t.o.v. 2019. Van de drie nieuwe EA's die werden toegevoegd in 2019 wordt de braak met drachtplanten het meest gekozen en daarna olifantsgras; de stijging hierin zet ook in 2020 door. Niet-productieve EA's (zoals landschapselementen, akkerranden, braakland) als percentage van EA-areaal blijft echter nog steeds erg laag. 
Tabel 5 Overzicht van outputindicatoren van de vergroening voor specifieke EA-maatregelen.

\begin{tabular}{|c|c|c|c|c|c|c|c|c|c|}
\hline & Jaar & Aantal boeren & $\begin{array}{r}\text { Opp. } \\
\text { landbouw- } \\
\text { grond (ha) }\end{array}$ & $\begin{array}{r}\% \text { landbouw- } \\
\text { grond* }\end{array}$ & $\begin{array}{r}\text { Opp. } \\
\text { bouwland } \\
\text { (ha) }\end{array}$ & $\begin{array}{r}\text { Opp. EA (ha) } \\
\text { (zonder } \\
\text { weging) }\end{array}$ & $\begin{array}{r}\text { Opp. EA (ha) } \\
\text { (met } \\
\text { weging) }\end{array}$ & $\begin{array}{l}\text { \% EA (zonder } \\
\text { weging) t.o.v. } \\
\text { opp. bouwland* }\end{array}$ & $\begin{array}{l}\% \text { van EA-areaal } \\
\text { (ongewogen)* }\end{array}$ \\
\hline \multirow[t]{6}{*}{ Aantal boeren met collectief EA } & 2015 & 12 & 689 & $0 \%$ & 656 & 169 & 55 & $0 \%$ & $0 \%$ \\
\hline & 2016 & 2 & 86 & $0 \%$ & 80 & 13 & 4 & $0 \%$ & $0 \%$ \\
\hline & 2017 & 7 & 347 & $0 \%$ & 315 & 31 & 52 & $0 \%$ & $0 \%$ \\
\hline & 2018 & 5 & 190 & $0 \%$ & 184 & 6 & 51 & $0 \%$ & $0 \%$ \\
\hline & 2019 & 3 & 99 & $0 \%$ & 99 & 23 & 7 & $23 \%$ & $0 \%$ \\
\hline & 2020 & 2 & 84 & $0 \%$ & 84 & 30 & 9 & $36 \%$ & $0 \%$ \\
\hline \multirow[t]{6}{*}{ Aantal boeren met EA-verplichting } & 2015 & 11430 & 679705 & $37 \%$ & 626250 & 161898 & 51245 & $26 \%$ & $100 \%$ \\
\hline & 2016 & 10655 & 635965 & $35 \%$ & 582736 & 191925 & 60378 & $33 \%$ & $100 \%$ \\
\hline & 2017 & 10585 & 644648 & $36 \%$ & 589209 & 201600 & 63195 & $34 \%$ & $100 \%$ \\
\hline & 2018 & 10799 & 658139 & $36 \%$ & 607948 & 210614 & 67615 & $35 \%$ & $100 \%$ \\
\hline & 2019 & 10772 & 661178 & $36 \%$ & 612521 & 218399 & 69851 & $36 \%$ & $100 \%$ \\
\hline & 2020 & 10839 & 675473 & $37 \%$ & 623247 & 222875 & 71507 & $36 \%$ & $100 \%$ \\
\hline \multirow[t]{6}{*}{ EA: Akkerranden } & 2015 & 904 & 58815 & $3 \%$ & 52474 & 1038 & 1038 & $0 \%$ & $1 \%$ \\
\hline & 2016 & 903 & 57902 & $3 \%$ & 52571 & 875 & 875 & $0 \%$ & $0 \%$ \\
\hline & 2017 & 917 & 60019 & $3 \%$ & 52940 & 904 & 904 & $0 \%$ & $0 \%$ \\
\hline & 2018 & 855 & 53751 & $3 \%$ & 48844 & 862 & 863 & $0 \%$ & $0 \%$ \\
\hline & 2019 & 755 & 49975 & $3 \%$ & 45211 & 761 & 761 & $0 \%$ & $0 \%$ \\
\hline & 2020 & 800 & 52326 & $3 \%$ & 47602 & 814 & 814 & $0 \%$ & $0 \%$ \\
\hline \multirow[t]{6}{*}{ EA: Wilgenhakhout } & 2015 & 6 & 584 & $0 \%$ & 399 & 15 & 5 & $0 \%$ & $0 \%$ \\
\hline & 2016 & 8 & 629 & $0 \%$ & 427 & 21 & 6 & $0 \%$ & $0 \%$ \\
\hline & 2017 & 10 & 769 & $0 \%$ & 535 & 22 & 7 & $0 \%$ & $0 \%$ \\
\hline & 2018 & 7 & 440 & $0 \%$ & 391 & 16 & 8 & $0 \%$ & $0 \%$ \\
\hline & 2019 & 8 & 437 & $0 \%$ & 406 & 21 & 10 & $0 \%$ & $0 \%$ \\
\hline & 2020 & 12 & 681 & $0 \%$ & 580 & 25 & 12 & $0 \%$ & $0 \%$ \\
\hline \multirow[t]{6}{*}{ EA: Vanggewassen } & 2015 & 9034 & 567488 & $31 \%$ & 527488 & 155908 & 46775 & $33 \%$ & $96 \%$ \\
\hline & 2016 & 9344 & 572158 & $32 \%$ & 529740 & 185571 & 55675 & $33 \%$ & $97 \%$ \\
\hline & 2017 & 9611 & 595 & $33 \%$ & 548610 & 195147 & 58549 & $34 \%$ & $97 \%$ \\
\hline & 2018 & 9896 & 612303 & $34 \%$ & 568897 & 204475 & 61347 & $34 \%$ & $97 \%$ \\
\hline & 2019 & 9911 & 616891 & $34 \%$ & 574531 & 212423 & 63732 & $35 \%$ & $97 \%$ \\
\hline & 2020 & 9958 & 630018 & $35 \%$ & 585585 & 216526 & 64962 & $35 \%$ & $97 \%$ \\
\hline
\end{tabular}




\begin{tabular}{|c|c|c|c|c|c|c|c|c|c|}
\hline & Jaar & Aantal boeren & $\begin{array}{r}\text { Opp. } \\
\text { landbouw- } \\
\text { grond (ha) }\end{array}$ & $\begin{array}{r}\% \text { landbouw- } \\
\text { grond* }\end{array}$ & $\begin{array}{r}\text { Opp. } \\
\text { bouwland } \\
\text { (ha) }\end{array}$ & $\begin{array}{r}\text { Opp. EA (ha) } \\
\text { (zonder } \\
\text { weging) }\end{array}$ & $\begin{array}{r}\text { Opp. EA (ha) } \\
\text { (met } \\
\text { weging) }\end{array}$ & $\begin{array}{r}\% \text { EA (zonder } \\
\text { weging) t.o.v. } \\
\text { opp. bouwland } *\end{array}$ & $\begin{array}{r}\% \text { van EA-areaal } \\
\text { (ongewogen)* }\end{array}$ \\
\hline \multirow[t]{6}{*}{ EA: N-bindende gewassen } & 2015 & 850 & 65614 & $4 \%$ & 56627 & 4937 & 3427 & $1 \%$ & $3 \%$ \\
\hline & 2016 & 904 & 70299 & $4 \%$ & 61611 & 5458 & 3821 & $0 \%$ & $3 \%$ \\
\hline & 2017 & 1027 & 79418 & $4 \%$ & 69221 & 5970 & 4179 & $0 \%$ & $3 \%$ \\
\hline & 2018 & 1021 & 72350 & $4 \%$ & 63345 & 5101 & 5101 & $1 \%$ & $2 \%$ \\
\hline & 2019 & 968 & 69574 & $4 \%$ & 60485 & 4795 & 4795 & $1 \%$ & $2 \%$ \\
\hline & 2020 & 988 & 72500 & $4 \%$ & 92419 & 5013 & 5013 & $1 \%$ & $2 \%$ \\
\hline \multirow[t]{6}{*}{ EA: Landschapselementen } & 2015 & 0 & 0 & $0 \%$ & 0 & 0 & 0 & $0 \%$ & $0 \%$ \\
\hline & 2016 & 147 & 10232 & $1 \%$ & 9228 & 166 & 265 & $0 \%$ & $0 \%$ \\
\hline & 2017 & 519 & 33889 & $2 \%$ & 28749 & 111 & 203 & $0 \%$ & $0 \%$ \\
\hline & 2018 & 579 & 37023 & $2 \%$ & 32048 & 159 & 293 & $0 \%$ & $0 \%$ \\
\hline & 2019 & 648 & 42609 & $2 \%$ & 36910 & 168 & 314 & $0 \%$ & $0 \%$ \\
\hline & 2020 & 661 & 44296 & $2 \%$ & 38336 & 189 & 354 & $0 \%$ & $0 \%$ \\
\hline \multirow[t]{2}{*}{ EA: Olifantsgras } & 2019 & 28 & 1844 & $0 \%$ & 1713 & 136 & 95 & $0 \%$ & $0 \%$ \\
\hline & 2020 & 32 & 2082 & $0 \%$ & 1839 & 140 & 98 & $0 \%$ & $0 \%$ \\
\hline \multirow[t]{2}{*}{ EA: Zonnekroon } & 2019 & 1 & 89 & $0 \%$ & 89 & 0 & 0 & $0 \%$ & $0 \%$ \\
\hline & 2020 & 2 & 255 & $0 \%$ & 213 & 1 & 1 & $0 \%$ & $0 \%$ \\
\hline \multirow[t]{2}{*}{ EA: Braak met drachtplanten } & 2019 & 86 & 5780 & $0 \%$ & 5011 & 95 & 143 & $0 \%$ & $0 \%$ \\
\hline & 2020 & 136 & 10985 & $1 \%$ & 8794 & 168 & 253 & $0 \%$ & $0 \%$ \\
\hline
\end{tabular}

* Om de leesbaarheid te bevorderen, zijn alleen afgeronde getallen gebruikt. Dit betekent dat $0 \%$ in de tabel niet een absolute 0 hoeft te zijn. 


\section{Conclusies resultaten van vergroening na vijf jaar}

De vergroeningsmaatregelen hebben in Nederland een grote reikwijdte, in die zin dat een groot gedeelte van het landbouwareaal in beheer is bij boeren met minimaal één vergroeningsverplichting. Dit areaal is tussen 2015 en 2020 ook toegenomen. In 2015 had 67\% van de boeren ten minste één vergroeningsverplichting en in 2018 was dit gestegen naar $74 \%$ en op dat niveau zit het in 2020 nog steeds. Dit wordt vooral verklaard door een stijging in het aantal boeren met een instandhoudingsverplichting blijvend grasland. De landbouwgrond die hoort bij deze bedrijven (met minimaal één vergroeningsverplichting) bedroeg 90\% in 2015, steeg naar 93\% in 2016 en daalde toen naar een constant percentage van $92 \%$ vanaf 2017 t/m 2020. Gesteld kan worden dat Nederland hiermee hoog scoort in Europees perspectief, waar het gemiddelde percentage landbouwgrond dat ten minste onder één verplichting valt in 2017 op 73\% lag (Europese Rekenkamer, 2017). Dit hoge percentage landbouwgrond met ten minste één vergroeningsverplichting betekent niet dat er veel is veranderd in de landbouwpraktijk op bedrijven.

Ten eerste omdat dit percentage geldt voor alle bedrijven met blijvend grasland. Deze bedrijven maken 63\% van de bedrijven in Nederland uit in 2019 en in 2020, een stijging ten opzichte van het voorgaande jaar 2018 met $1 \%$ en ten opzichte van 2015 met 7\%. Ten tweede voegt de maatregel gewasdiversificatie weinig toe aan de gangbare landbouwpraktijk. Tussen 2015 en 2017 steeg het aandeel boeren dat zich hieraan moet houden wel van $22 \%$ naar $24 \%$, waarna het op $24 \%$ is gebleven tussen 2016 en 2020. Het areaal dat hierbij hoorde, nam in absolute zin af, maar bleef relatief wel constant. In de praktijk is echter de diversiteit in hoofdgewassen in de vergroeningsperiode 2015-2017 sterk afgenomen, zoals bleek uit cijfers gepresenteerd in Elbersen et al. (2018). Ten derde geldt ook voor de maatregel EA dat deze maar op een klein aandeel van het landbouwareaal tot een verandering in de landbouwpraktijk leidt. In 2020 is $20 \%$ van de boeren met $36 \%$ van het landbouwareaal verplicht aan deze maatregel te voldoen en het EA-areaal dat hierbij hoort, beslaat 218399 ha (ongewogen) en 71507 ha (gewogen). Dit komt neer op 11\% van het landbouwareaal met betalingsrechten. Overigens valt Nederland hiermee boven het Europese gemiddelde wat betreft relatief areaal EA dat boven de $5 \%$ moet liggen.

De bedrijven (63\% in 2020) in Nederland met een instandhoudingsverplichting voor blijvend grasland moeten hun areaal blijvend grasland rapporteren in hun jaarlijkse perceelopgave. Voor deze bedrijven geldt dat zij - om de vergroeningspremie te ontvangen - geen aanvullende maatregelen hoeven te treffen, tenzij dit BG in Natura 2000-gebied ligt, want dat is aangewezen als Ecologisch Kwetsbaar Blijvend Grasland (EKBG) en daarvoor geldt een omzet- en ploegverbod. Dit geldt voor 10\% van de bedrijven met BG en $6 \%$ van het totaalaantal bedrijven in Nederland. Voor $57 \%$ van de bedrijven die BG hebben gelegen buiten Natura 2000 gelden dus geen aanvullende maatregelen, zolang de daling van het relatieve areaal blijvend grasland in het totale landbouwareaal niet meer dan $5 \%$ bedraagt ten opzichte van de blijvend grasland-ratio in het referentiejaar 2012. In 2020 was dit zeker niet het geval, want er was zelfs sprake van een stijging van 2,29\% ten opzichte van de referentieratio. Deze stijging hangt waarschijnlijk samen met afschaffing van het melkquotum en aanpassing van de mestderogatienormen, wat gestimuleerd heeft dat boeren meer permanent grasland op hun bedrijf zijn gaan aanhouden. Dit was vooral het geval in Zuid-Nederland.

Het totaal aantal hectaren blijvend grasland met een ploeg- en omzetverbod, het zogenaamde EKBG, betreft 59804 ha in 2020. Een overgroot deel wordt gehandhaafd onder de vergroeningverplichting op boerenbedrijven. Het aantal boeren met EKBG grasland bedraagt 3258 in 2020 en zij beheren 41677 ha blijvend grasland. Het overgrote deel van hun grasland valt dus in de EKBG-categorie en dit betreft $5 \%$ van het totaal areaal blijvend grasland in Nederland in 2020. Nederland heeft ervoor gekozen om 100\% van het blijvend graslandareaal binnen Natura 2000 aan te wijzen als kwetsbaar. Dit komt overeen met een areaal van 59804 ha ( $8 \%$ van het totale BG-areaal). Slechts een deel van dit gebied valt echter onder het beheer van vergroeningsplichtige boeren en verklaart het grote 
verschil tussen aangewezen hectaren ecologisch kwetsbaar blijvend grasland (EKBG) en opgegeven hectaren onder vergroening.

Met het areaal EA kan in potentie een goede bijdrage geleverd worden aan natuur en biodiversiteit door het seminatuurlijke areaal op agrarisch land te vergroten. Dit was ook de oorspronkelijke bedoeling van de maatregel. Het merendeel van de boeren in Nederland heeft ervoor gekozen om EA's in te vullen met productiegerelateerde EA's als vang- en stikstofbindende gewassen, die hierdoor gemiddeld $99 \%$ van het EA-areaal beslaan over de onderzochte periode van 2015 tot met 2020. Deze gewassen kunnen een positieve bijdrage leveren aan de bodem, hoewel nog onderzocht moet worden of deze bijdrage optimaal is, gegeven de korte tijd dat ze op het land staan; ze dragen echter vrijwel niets bij aan het verbeteren van natuur en biodiversiteit. Overigens heeft Nederland hiermee wel een uitzonderingspositie in de EU, waar gemiddeld $58 \%$ van het areaal wordt ingevuld met productiegerelateerde EA's als vang- en stikstofbindende gewassen. Samen met Roemenië was Nederland het enige land dat op 99\% invulling van EA met vanggewassen en stikstofbindende gewassen uitkwam in de beginjaren van het vergroeningsbeleid (EC, ECA-data 2016). Aangezien dit percentage tussen 2015 en 2020 niet afgenomen is, zal dit nog steeds het geval zijn.

De interesse voor participatie in equivalente maatregelen lag niet bijzonder hoog onder boeren in Nederland. Op het hoogtepunt in 2017 bedroeg dit 1\% van het aantal boeren en $2 \%$ van het landbouwareaal. Echter, door aanpassingen in de voorwaarden in de standaardsituatie in relatie tot vanggewassen is de participatie in het Veldleeuwerikpakket niet meer aantrekkelijk, wat uiteindelijk in 2020 tot afschaffing van het pakket heeft geleid. Overigens heeft deze aanpassing in de standaardsituatie ook tot daling in de belangstelling voor de twee andere equivalente pakketten in 2020 geleid. Kortom, equivalente maatregelen kunnen niet meer een interessant alternatief worden genoemd.

Voor zowel het vastleggen van bodemkoolstof als het beschermen van onder- en bovengrondse biodiversiteit, is het in stand houden van blijvend grasland belangrijk. Nederland heeft ervoor gekozen om $100 \%$ van het blijvend grasland in Natura 2000-gebied aan te wijzen als EKBG. Hierdoor geldt alleen binnen Natura 2000-gebieden een ploeg- en omzetverbod voor blijvend gras. Bescherming van blijvend grasland op basis van EU-regelgeving is ook toegestaan in andere gebieden, zoals weidevogelgebieden en veenweidegebieden, die in Nederland grotendeels buiten Natura 2000-gebied liggen.

Bij aanwijzing van kwetsbare graslanden scoort Nederland onder het EU-gemiddelde, waar gemiddeld $16 \%$ van de blijvende graslanden als kwetsbaar is aangewezen. In Nederland is $100 \%$ van het blijvend grasland in Natura 2000-gebied aangewezen als kwetsbaar, hetgeen betekent dat voor 5\% van het blijvend grasland een ploeg- en omzetverbod geldt. Dit niveau schommelt ook in voorgaande jaren rond die $5 \%$.

Tot slot kan men concluderen dat uit de resultaten blijkt dat de vergroeningsmaatregelen weinig effectief zijn in de bijdrage aan het behalen van natuur- en biodiversiteitsdoelen. Dit komt doordat de maatregelen op een beperkt areaal van toepassing zijn, de maatregelen zelf van weinig toegevoegde waarde zijn ten opzichte van de gangbare landbouwpraktijk en omdat het mogelijk is voor laagdrempelige, maar weinig effectieve EA-opties te kiezen. Dit sluit aan bij de conclusies die de Europese Rekenkamer (2017) ook na evaluatie van vergroening op EU-niveau heeft getrokken en hierin is tussen 2018 en 2020 niets veranderd. 


\section{Literatuur}

Doorn, A. van, Vullings, W. \& Smidt, R., 2015. Nationale monitoring en evaluatie van de vergroening van het GLB. Systematiek en nulmeting. Wageningen Alterra Wageningen UR, Alterra rapport 2606.

Doorn, A. van \& Smidt, R., 2017. Feiten en cijfers vergroening GLB. Wageningen Environmental Research. Rapport 2795.

Elbersen, B.S. Smidt R. \& Doorn van A. 2018. Feiten en cijfers vergroening GLB 2017. Wageningen, Wageningen Environmental Research Rapport 2907. 36 blz.; 2 fig.; 10 tab.; 7 ref.

Elbersen, B.S. \& Schutt, J. (2019). Feiten en cijfers vergroening GLB 2018. Wageningen Environmental Research Rapport | ISSN 1566-7197

EC, 2016. Commission staff working document. Review of Greening after one year. SWD (2016) 218 final. Parts 1-6. Brussels 22nd of June 2016.

Ecorys, IEEP, WUR, 2016 Mapping and analysis of the implementation of the CAP https://ec.europa.eu/agriculture/sites/agriculture/files/external-studies/2016/mapping-analysisimplementation-cap/fullrep_en.pdf)

Europese Rekenkamer/European Court of Auditors, 2017. Greening: a more complex income support scheme, not yet environmentally effective. Report no. 21

Hart, K., 2015. 'Green direct payments: implementation choices of nine Member States and their environmental implications'

Louhichi, K., Ciaian, P., Espinosa, M, Perni, A., Gomez y Paloma, S., (2017). Economic impacts of CAP Greening; An application of an EU-wide individual farm model for CAP analysis (IFM-CAP), European Review of agricultural Economics, forthcoming.

\section{Websites}

Basisbetaling en Nationale Reserve: https://www.rvo.nl/onderwerpen/agrarischondernemen/gemeenschappelijk-landbouwbeleid/gemeenschappelijk-landbouwbeleid/directe-glbsteun/basisbetaling-en-nationale

CBS blijvend grasland: https://www.cbs.nl/nl-nl/nieuws/2016/21/voor-het-eerst-in-9-jaar-meerblijvendgrasland\# : : text=De\%20oppervlakte\%20blijvend\%20grasland\%20is,naar\%20ruim\%20714\%20d uizend\%20hectare.\&text=De\%20stijging\%20van\%20het\%20areaal,procent\%20en\%2030\%20pro cent\%20toe. 


\section{Bijlage 1 Invulling van \\ vergroeningsmaatregelen in Nederland}

Bij de invulling van de vergroeningsmaatregelen op nationaal niveau heeft de EU de lidstaten veel ruimte gegeven om eigen keuzes te maken ten aanzien van de invulling. Hieronder wordt besproken hoe die invulling in Nederland is.

\section{Gewasdiversificatie}

Bij de invulling van de gewasdiversificatiemaatregel heeft de EU geen vrijheid gegeven aan de lidstaten voor nationale invulling. In alle lidstaten gelden daarom dezelfde verplichtingen en die schrijven voor dat bedrijven met tussen de 10 en 30 ha bouwland minimaal twee gewassen en bedrijven met meer dan 30 ha bouwland minimaal drie gewassen moeten telen. Bedrijven kunnen vrijstelling van gewasdiversificatie krijgen in de volgende gevallen:

1. Biologische bedrijven worden vrijgesteld voor de percelen waarop biologische productie plaatsheeft.

2. Als vorig jaar op een bedrijf meer dan $50 \%$ van het bouwland niet voorkomt in de steunaanvraag van de betreffende landbouwer en op de andere $50 \%$ bouwland een ander gewas is verbouwd dan er vorig jaar op dat perceel stond.

3. Als de oppervlakte bouwland op een bedrijf, inclusief tijdelijk grasland, niet meer dan 10 ha bedraagt.

4. Als de oppervlakte landbouwgrond op een bedrijf voor meer dan $75 \%$ wordt gebruikt voor de productie van grassen of andere kruidachtige voedergewassen, braak ligt of voor een combinatie daarvan wordt gebruikt, mits het akkerbouwareaal dat daar niet onder valt niet meer dan 30 ha groot is. ${ }^{9}$

Voor bedrijven met gewasdiversificatieverplichting geldt tevens dat het grootste gewas niet meer dan $75 \%$ van het bouwland mag beslaan. Bij een verplichting voor gewasdiversificatie met drie gewassen geldt tevens dat de twee grootste gewassen samen niet meer dan 95\% van de oppervlakte bouwland mogen beslaan.

\section{Ecologische aandachtsgebieden}

Nederland heeft gekozen voor de invulling met vijf ecologische aandachtsgebieden (EA's) uit de algemene lijst. Hiermee heeft Nederland gekozen voor een selectieve invulling van EA's. De vijf gekozen EA's zijn vang- en stikstofbindende gewassen, wilgenhakhout, akkerrand en met ingang van 2016 ook landschapselementen. ${ }^{10}$

Bij de invoering van vergroening is er de meeste discussie geweest over de invoering van de EA's, zoals reeds omschreven in Van Doorn (et al., 2015). Enerzijds wordt van EA's de grootste ecologische meerwaarde verwacht als deze worden ingevuld met niet-productief gebruikte elementen als (liefst meerjarige) akkerranden, bufferstroken en braakland. Echter, bij de invoering was ook veel weerstand bij de landbouwsector, die negatieve economische effecten verwachtte van het uit productie nemen van $5 \%$ van het landbouwareaal. Bij invoering van de EA's zijn daardoor - naast de akkerranden en landschapselementen - ook vanggewassen en stikstofbindende gewassen opgenomen in de Europese longlist en Nederland heeft deze beide typen gewassen ook opgenomen in de nationale lijst.

Tegelijkertijd heeft Nederland er ook voor gekozen om braak niet op te nemen in de nationale lijst, terwijl die wel op de Europese longlist voorkomt en ook door de meeste andere Europese lidstaten gekozen is. Vanwege de grote verscheidenheid in EA's en het verschil in potentiële ecologische

\footnotetext{
9 Op 1 januari 2018 zijn er technische aanpassingen van het Gemeenschappelijk landbouwbeleid (GLB) in werking getreden via de Omnibusverordening (2017/2393). Hierdoor geldt vanaf 2018 1) de vrijstelling voor gewasdiversificatie ook voor bedrijven met meer dan $75 \%$ vlinderbloemige gewassen en 2 ) is de 30 ha-grens voor het overige akkerbouwareaal komen te vervallen.

${ }^{10}$ Overigens worden vanaf 2019 drie nieuwe EA's toegevoegd in Nederland: gebieden met Miscanthus, gebieden in groene braak met Silphium perfoliatum of met melliferous (honingrijke) planten.
} 
meerwaarde en economische kosten, is er ook een systematiek aan omzettings- en wegingsfactoren aan typen EA's verbonden. Een overzicht van deze wegingsfactoren voor de EA's die Nederland heeft gekozen, is te vinden in bijlage 2 .

Landschapselementen hebben een weegfactor variërend van 1,5 tot 2 vanwege de grotere potentiële bijdrage aan biodiversiteit. Dit betekent dat bijvoorbeeld houtwallen met een oppervlakte van 1 ha, die een wegingsfactor van 2 hebben, voor 2 ha meetellen als ecologisch aandachtsgebied. Bij invulling met niet-productieve EA's, zoals landschapselementen of beheerde akkerranden, hoeft men dus minder dan $5 \%$ van het bouwland als EA in te richten. Landschapselementen als heggen, houtwallen en bomen in rij hebben met 2 de hoogste wegingsfactor van alle EA's.

De gewassen die in Nederland als vanggewas (onderzaai of nateelt) worden gebruikt, zijn genoemd in bijlage 2 . In bijlage 2 worden ook de stikstofbindende gewassen genoemd die kunnen worden ingezet. De laatste zijn ingedeeld in drie categorieën, waarbij bepaalde gewassen in meerdere categorieën voorkomen. Categorie 1 betreft de algemene categorie vanggewassen, categorie 2 betreft vanggewassen die helpen bij de bestrijding van aaltjes - en mogen bij uitzondering in combinatie met gewasbeschermingsmiddelen gebruikt worden ${ }^{11}$ - en categorie 3 betreft alle tijdelijke en blijvende grassoorten die in Nederland gebruikt worden en met ingang van 2018 kan categorie 3 ook bestaan uit gras en/of vlinderbloemigen. Overigens hoeft er geen sprake te zijn van een mengsel, monoteelt is ook toegestaan.

In tabel B1.1 is aangegeven welke bedrijven vrijgesteld zijn van EA's. Alle bedrijven met meer dan 30 ha bouwland zijn in ieder geval EA-plichtig. Bedrijven die tot 15 ha bouwland hebben of biologisch zijn (een SKAL-nummer hebben), zijn vrijgesteld van EA.

Tabel B1.1 Overzicht van kenmerken waarbij EA verplicht en niet verplicht is.

\begin{tabular}{|c|c|}
\hline Kenmerk & Vrijgesteld van EA \\
\hline $\begin{array}{l}\text { Oppervlakte bouwland tussen }>15-30 \text { ha en }>75 \% \\
\text { uit tijdelijk grasland, braak en vlinderbloemigen of } \\
\text { combinatie daarvan }\end{array}$ & Vrijgesteld \\
\hline $\begin{array}{l}>15-30 \text { ha en }>75 \% \text { uit tijdelijk grasland en blijvend } \\
\text { grasland }\end{array}$ & Vrijgesteld \\
\hline Oppervlakte bouwland > 30 ha & EA-plichtig \\
\hline
\end{tabular}

Nederland heeft bij de invulling van EA ook gekozen voor de collectieve invulling. Dit geldt voor landbouwers die met minimaal twee en maximaal tien landbouwers een collectief vormen (met collectieve overeenkomst gemeld bij RVO). Alle bedrijven die in dit collectief participeren, moeten bijeen liggen, dat wil zeggen dat $80 \%$ van de collectieve grond binnen een cirkel van $15 \mathrm{~km}$ bijeen ligt. De collectief ingebrachte EA's moeten aangrenzend zijn (niet gescheiden door sloot of weg). Bovendien mag een deelnemer maximaal 50\% van de eigen EA-verplichting laten invullen door een ander bedrijf in het collectief en is dus verplicht altijd $50 \%$ van de EA in te vullen op het eigen bedrijf. Uit het overzicht van resultaatindicatoren in hoofdstuk 2 zal echter blijken dat hier praktisch geen gebruik van wordt gemaakt.

Tot slot moet nog vermeld worden dat bepaalde EA's kunnen samenvallen met elementen die beheerd kunnen worden via agrarisch natuurbeheer (SAN/SN). Zet een agrariër dit agrarisch natuurbeheer geheel of gedeeltelijk in om aan de verplichting van EA te voldoen, dan is dit toegestaan. Echter zal er dan wel een korting komen op de betaling voor agrarisch natuurbeheer, anders is er sprake van dubbele betaling. Dit geldt voor EA's als vang- en stikstofbindende gewassen, akkerranden en wilgenhakhout, maar niet voor landschapselementen. De subsidie voor beheer van

${ }^{11}$ Vanaf 2018 zijn gewasbeschermingsmiddelen ook bij aaltjes niet langer toegestaan. 
landschapselementen wordt niet verlaagd bij overlap met EA, omdat beheer van deze elementen bij vergroening niet verplicht is, terwijl dit juist wel het doel is van de agrarisch-natuurbeheerregeling.

\section{In stand houden van blijvend grasland}

In de vergroening zijn eigenlijk twee maatregelen van toepassing, met als doel het in stand houden van blijven grasland. Enerzijds moet blijvend grasland gemonitord worden op nationaal niveau, zodat op tijd ingegrepen kan worden bij een daling van het areaal blijvend grasland met meer dan $5 \%$. Anderzijds geldt er een ploeg- en omzetverbod voor blijvend grasland gelegen in Natura 2000gebieden.

Bij de instandhouding van blijvend grasland heeft Nederland gekozen voor monitoring op nationaal en niet op regionaal of bedrijfsniveau. Dat betekent dat als het graslandareaal met meer dan $5 \%$ op nationaal niveau terugloopt ten opzichte van de referentieratio, Nederland ervoor moet zorgen dat het aandeel weer voldoende stijgt door het invoeren van een herinzaaiplicht. Dat laatste houdt in dat boeren verplicht worden een perceel met gras in te zaaien en dit blijvend grasland moet ook blijven. In Nederland ligt de referentieratio (gebaseerd op 2012) voor blijvend grasland in 2020 op 41,91\%. Door RVO is berekend dat er in 2020 sprake was van een relatieve toename in blijvend grasland van $2,29 \%$. Er is dus in 2020 geen reden om maatregelen te treffen.

Wat betreft de aanwijzing van kwetsbare blijvende graslanden heeft Nederland gekozen voor aanwijzing van $100 \%$ van het blijvend grasland binnen Natura 2000 -gebieden voor een ploeg- en omzetverbod. Bij nationale vergroeningsinvulling heeft de EU aan landen ook de vrijheid gegeven om blijvende graslandgebieden buiten Natura 2000-gebieden aan te wijzen voor een ploeg- en omzetverbod. Dit kan gedaan worden met als doel van verbetering van de biodiversiteit, de bodemen waterkwaliteit, maar met name ter bescherming van het klimaat via koolstofvastlegging. Nederland heeft er echter, net als de grote meerderheid van de EU-landen, voor gekozen om kwetsbare graslandgebieden met een ploeg- en omzetverbod te beperken tot Natura 2000-gebieden.

Omdat instandhouding van blijvend grasland een vergroeningsverplichting is, vallen alle landbouwbedrijven met blijvend grasland automatisch onder de vergroeningsverplichting. Echter, voor boeren met blijvend grasland buiten Natura 2000-gebied leidt dit niet tot een bepaalde verplichting. Zij mogen grasland nog steeds omploegen en scheuren, zolang er geen sprake is van een nationale daling van meer dan $5 \%$, en dat is op dit moment bij lange na niet het geval. Voor boeren met blijvend grasland binnen Natura 2000-gebied geldt daarentegen wel een verplichting om zich aan het ploeg- en omzetverbod van blijvend grasland te houden. Overigens zijn er nog wel bepaalde vormen van lichte grondbewerking toegestaan in Natura 2000-gebieden, mits de ondergrond van het grasland vrijwel onberoerd blijft en er altijd een dekkende vegetatie zichtbaar blijft. De boeren met blijvend grasland in Natura 2000-gebieden zijn verplicht blijvend grasland ook als blijvend grasland te registreren in de perceelregistratie.

\section{Equivalente maatregelen}

In Nederland waren tot 2016 twee equivalente pakketten met een duurzaamheidscertificaat mogelijk: het Akkerbouwstrokenpakket en het pakket Veldleeuwerik. Vanaf 2016 kunnen boeren voor het pakket Vezelhennep ook een duurzaamheidscertificaat ontvangen en kan deze dus als equivalente maatregel dienen. In tabel B1.2 wordt aangegeven wat deze maatregelen inhouden en in hoeverre ze verschillen van de standaard vergroeningsverplichtingen. 
Tabel B1.2 Equivalente pakketten in Nederland 2015-2019 (enkele voorwaarden zijn in 2019 gewijzigd).

Equivalent pakket

Akkerbouwstrokenpakket

\section{Beschrijving pakket}

Dit is een pakket waarvoor akkerranden met beheereisen gelden. De stroken moeten tussen de 3 en $20 \mathrm{~m}$ breed zijn. Deze stroken (tot maximaal $20 \mathrm{~m}$ breed) mogen (geheel of gedeeltelijk) worden ingezet als EA. ${ }^{12}$

$30 \%$ van de totale EA-verplichting moet akkerrand zijn en 50\% moet overwinteren. Sloot naast beheerde rand mag meetellen.

Vanaf 2019 kunnen er hybride soorten vanggewassen (grassen) ingezet worden. Hiervoor gelden dezelfde voorwaarden als bij de Algemene Lijst.

Pakket vezelhennep ${ }^{13}$
Akkerbouwers met dit certificaat moeten hun EA-verplichting invullen met de teelt van hennep. Ten minste $50 \%$ van de EA-verplichting moet ingevuld worden met vezelhennep. De andere 50\% wordt ingevuld met vanggewassen. Percelen met hennep hebben een wegingsfactor van 0,3 ( 1 ha hennep telt mee voor 0,3 ha vergroening). Telers die gebruikmaken van het duurzaamheidscertificaat Vezelhennep dienen hun EA-verplichting volledig in te vullen met de teelt van vezelhennep. Op die percelen mag tussen het moment van zaaien en het moment van oogsten geen gewasbeschermingsmiddel worden toegepast.

Vanaf 2019 kunnen er hybride soorten vanggewassen (grassen) ingezet worden. Hiervoor gelden dezelfde voorwaarden als bij de Algemene Lijst.

\footnotetext{
${ }^{12}$ Stroken mogen breder zijn dan $20 \mathrm{~m}$, maar slechts $20 \mathrm{~m}$ telt mee voor de EA-verplichting. Op de breedte wordt de factor 3 toegepast. Een rand van $60 \mathrm{~m}$ breed kan voor $20 \mathrm{~m}$ meetellen.

${ }^{13}$ Wijziging: met ingang van 2018 mag het areaal ook met vanggewassen worden ingevuld, mits meer dan $50 \%$ nog steeds uit vezelhennep bestaat.
} 


\section{Bijlage 2 Overzicht voorwaarden en wegingsfactoren voor ecologische aandachtsgebieden 2019 (Algemene lijst)}

\begin{tabular}{|c|c|c|c|}
\hline Type EA & $\begin{array}{l}\text { Wegings- } \\
\text { factor }\end{array}$ & Voorwaarden & Toegestane soorten \\
\hline $\begin{array}{l}\text { Stikstofbindende } \\
\text { gewassen }\end{array}$ & 1 & $\begin{array}{l}\text { - Een van de toegestane soorten inzaaien. Dit } \\
\text { mag ook een mengsel zijn waarbij het totaal } \\
\text { aan stikstofbindende gewassen overheerst } \\
\text { (meer dan } 50 \% \text { ). } \\
\text { - Nateelt van een van de vanggewassen } \\
\text { algemeen (categorie } 1 \text { ) verplicht op zanden en } \\
\text { lössgronden als de teelt voor } 1 \text { oktober wordt } \\
\text { beëindigd. Deze nateelt is aanwezig van } \\
1 \text { november tot } 1 \text { maart. } \\
\text { - Bij soja (Glycine) is het gebruik van } \\
\text { stikstofmeststoffen niet toegestaan. } \\
\text { - Gebruik van gewasbeschermings-middelen mag } \\
\text { niet. Ook niet op het zaaizaad (ontsmet, gecoat } \\
\text { of gepilleerd). } \\
\text { - Het stikstofbindende gewas moet in de periode } \\
\text { van } 15 \text { mei tot } 15 \text { juli geteeld worden. } \\
\text { - Bij gebruik van een zaaizaadmengsel bewaart u } \\
\text { de aankoopbewijzen en etiketten van het } \\
\text { gebruikte zaaizaadmengsel gedurende } 5 \text { jaar in } \\
\text { uw administratie en kunt u aantonen dat in het } \\
\text { mengsel één of meer toegestane } \\
\text { stikstofbindende gewassen overheersen. } \\
\text { - U geeft in de Gecombineerde opgave de } \\
\text { gewascode op van het stikstofbindende gewas } \\
\text { dat in het mengsel het grootste aandeel heeft. }\end{array}$ & $\begin{array}{l}\text { Veldbonen (o.a. duiven-, } \\
\text { paarden-, wierbonen), luzerne, } \\
\text { niet-bittere lupinen, sojabonen, } \\
\text { afrikaantje, rode klaver, } \\
\text { rolklaver, esparcette, } \\
\text { voederwikke }\end{array}$ \\
\hline Wilgenhakhout & 0,5 & $\begin{array}{l}\text { - Maximale omlooptijd van } 5 \text { jaar. } \\
\text { - Gebruik meststoffen en } \\
\text { gewasbeschermingsmiddelen niet toegestaan. }\end{array}$ & Wilg \\
\hline $\begin{array}{l}\text { Olifantsgras en } \\
\text { zonnekroon (sinds } \\
\text { 2019) }\end{array}$ & 0,7 & $\begin{array}{l}\text { - Gebruik meststoffen niet toegestaan. } \\
\text { - Gebruik gewasbeschermingsmiddelen alleen in } \\
\text { het eerste jaar dat u aanplant, toegestaan. } \\
\text { - Beide gewassen worden gezien als blijvende } \\
\text { teelt. }\end{array}$ & \\
\hline $\begin{array}{l}\text { Braak met } \\
\text { drachtplanten (sinds } \\
\text { 2019) }\end{array}$ & 1,5 & $\begin{array}{l}\text { a. Mengsel van minimaal } 3 \text { toegestane soorten } \\
\text { drachtplanten inzaaien. Kijk voor de toegestane } \\
\text { soorten in de tabel bloeiperioden drachtplanten } \\
2019 \text { hieronder. Er moet een zichtbare } \\
\text { bedekking zijn waarbij de drachtplanten } \\
\text { overheersen. } \\
\text { b. De grond moet minimaal } 6 \text { maanden braak } \\
\text { blijven liggen in de periode van } 15 \text { maart tot en } \\
\text { met } 15 \text { november. Dit betekent dat de } \\
\text { braakperiode op zijn vroegst } 15 \text { maart en op } \\
\text { zijn laatst op } 16 \text { mei kan beginnen. Het land } \\
\text { mag in deze periode niet gebruikt worden voor } \\
\text { landbouwproductie. Dit betekent dat u het niet } \\
\text { mag maaien of begrazen. Wel mag u er } \\
\text { bijenkasten plaatsen. }\end{array}$ & $\begin{array}{l}\text { Drachtplanten: Karwij, } \\
\text { Koriander, wilde peen, } \\
\text { duizendblad, goudsbloem, } \\
\text { korenbloem, chicorei, } \\
\text { zonnebloem, kokommer-kruid, } \\
\text { slangenkruid, phacelia, gele } \\
\text { mosterd, gewone rolklaver, } \\
\text { luzerne, witte honingklaver, } \\
\text { esparcette, rode klaver, } \\
\text { incarnaat klaver, voederwikke, } \\
\text { lijnzaad/vlas, malva, klaproos, } \\
\text { boekweit, juffertje in het groen } \\
\text { en smalle weegbree }\end{array}$ \\
\hline
\end{tabular}




\begin{tabular}{|c|c|c|c|}
\hline Type EA & $\begin{array}{l}\text { Wegings- } \\
\text { factor }\end{array}$ & Voorwaarden & Toegestane soorten \\
\hline & & $\begin{array}{l}\text { c. Op de eerste dag van de periode van } \\
6 \text { maanden moet het zaaizaadmengsel } \\
\text { ingezaaid zijn. Bij meerjarige drachtplanten } \\
\text { hoeft u een volgend jaar niet opnieuw in te } \\
\text { zaaien. De nog aanwezige drachtplanten } \\
\text { moeten dan in de volgende braakperiode van } \\
6 \text { maanden wel voldoen aan alle verdere eisen. } \\
\text { d. Van mei tot en met augustus moet er steeds } \\
\text { minimaal } 1 \text { soort van de drachtplanten in bloei } \\
\text { staan. De bloeiperiode staat in de tabel Braak } \\
\text { met drachtplanten hieronder. } \\
\text { e. De } 3 \text { soorten drachtplanten mogen gemengd } \\
\text { worden met de soorten roodzwenkgras, } \\
\text { rietzwenkgras, veldbeemgras, Japanse haver, } \\
\text { Dille, Pastinaak, Gele ganzenbloem, Kleine } \\
\text { zonnebloem, Margriet, Echte kamille, } \\
\text { Barbarakruid, Bladrammenas, Bolderik, Lupine, } \\
\text { Serradella, Kleine klaver, Alexandrijnse klaver, } \\
\text { Erwt, Hennepnetel, Veldzuring, Wilde } \\
\text { ridderspoor of Timothee. Wel moeten de } \\
\text { drachtplanten overheersen. } \\
\text { f. Gebruik gewasbeschermingsmiddel of } \\
\text { meststoffen mag niet in de braakperiode. } \\
\text { g. In de Gecombineerde opgave de begindatum } \\
\text { aangeven van de periode van } 6 \text { maanden. } \\
\text { g. Aankoopbewijzen en etiketten van het } \\
\text { gebruikte zaaizaad(mengsel) } 5 \text { jaar lang } \\
\text { bewaren. }\end{array}$ & \\
\hline $\begin{array}{l}\text { Vanggewassen cat. } 1 \text { : } \\
\text { Algemeen vanggewas }\end{array}$ & 0,3 & $\begin{array}{l}\text { - Mengsel van minimaal } 2 \text { toegestane soorten } \\
\text { inzaaien. Kijk voor de toegestane soorten in de } \\
\text { tabel Gewassen en GLB } 2020 \text {. Inzaaien na } \\
\text { oogsten hoofdteelt en na } 15 \text { juli en uiterlijk } \\
15 \text { oktober. Bij inzaai op of voor } 15 \text { juli start de } \\
8 \text { wekentermijn altijd op } 15 \text { juli. }{ }^{14} \\
\text { - Minimaal } 8 \text { weken op het land. Tijdens de } \\
8 \text { wekenperiode geen activiteiten verrichten die } \\
\text { het gewas en de doelstelling ervan (stikstof } \\
\text { opvangen) kunnen beschadigen. O.a. begrazen, } \\
\text { maaien/klepelen zijn niet toegestaan. } \\
\text { - Meststoffengebruik mag. Gebruik } \\
\text { gewasbeschermingsmiddel mag niet vanaf } \\
\text { moment van oogst hoofdgewas en t/m de } \\
8 \text { wekenperiode dat het vanggewas minimaal op } \\
\text { het land moet staan. Vanggewassen na maïs op } \\
\text { zand- en lössgronden tellen niet mee. } \\
\text { - Ten minste } 75 \% \text { van de in de Aanbevelende } \\
\text { Rassenlijst voor landbouwgewassen (CSAR) } \\
\text { aanbevolen hoeveelheid zaaizaad gebruiken of } \\
\text { zorg voor een voldoende zichtbare bedekking } \\
\text { van de bodem met het vanggewas. } \\
\text { - Bewaar aankoopbewijzen en etiketten van het } \\
\text { gebruikte zaaizaad(mengsel) } 5 \text { jaar lang. } \\
\text { - Het vanggewas mag geen wintergewas zijn dat } \\
\text { in het najaar wordt ingezaaid en in de winter of } \\
\text { voorjaar wordt geoogst. }\end{array}$ & $\begin{array}{l}\text { Cat. 1: Kapucijners, } \\
\text { groene/gele/groen en droog te } \\
\text { oogsten erwten, lupine, lijnzaad } \\
\text { van olievlas, vezelvlas, gele en } \\
\text { Ethiopische mosterd, } \\
\text { zwaardherik, (Japanse, rode, } \\
\text { Alexandrijnse, incarnaat \& witte) } \\
\text { Perzische) klaver, bonte en } \\
\text { voeder wikke, beemdlangbloem, } \\
\text { bladkool, bladraap, } \\
\text { bladrammenas, deder, (Engels, } \\
\text { Italiaans, Westerwolds) raaigras, } \\
\text { facelia, Franse boekweit, Niger, } \\
\text { rietzwenkgras, sarepte mosterd, } \\
\text { Soedangras, spurrie, Seradelle } \\
\text { stoppelknollen, timothee, } \\
\text { veldbeemdgras. }\end{array}$ \\
\hline
\end{tabular}

\footnotetext{
${ }^{14}$ Uitzondering hierop is cat. 2. Een cat. 2-vanggewas mag als hoofdteelt voor de EA worden ingezet, maar als vanggewas mag het ingezaaid worden na 15 juni.
} 


\begin{tabular}{|c|c|c|c|}
\hline Type EA & $\begin{array}{l}\text { Wegings- } \\
\text { factor }\end{array}$ & Voorwaarden & Toegestane soorten \\
\hline $\begin{array}{l}\text { Vanggewassen } \\
\text { aaltjesbestrijding } \\
\text { (cat. 2) }\end{array}$ & 0,3 & $\begin{array}{l}\text { - Mengsel van minimaal } 2 \text { toegestane soorten } \\
\text { inzaaien. Kijk voor de toegestane soorten in de } \\
\text { tabel Gewascodes en GLB 2020. Hybride } \\
\text { soorten vanggewassen die bestaan uit een } \\
\text { kruising van de in de lijst met vanggewassen } \\
\text { genoemde soorten uit Categorie } 2 \text { zijn mogelijk. } \\
\text { Ook in die gevallen is wel een mengsel nodig. } \\
\text { - Elke in het mengsel aanwezige soort moet } \\
\text { minimaal } 3 \% \text { van gewicht uitmaken. } \\
\text { - Uiterlijk } 15 \text { oktober inzaaien en moet } 8 \text { weken } \\
\text { op land staan. } \\
\text { - Rest idem als hierboven. }\end{array}$ & $\begin{array}{l}\text { Cat. 2: Afrikaantje, raketblad, } \\
\text { zwaardherik, Japanse klaver } \\
\text { Cat. 3: tijdelijk gras, (Engels, } \\
\text { Italiaans, Westerwolds) raaigras, } \\
\text { Soedangras, spurrie en } \\
\text { veldbeemdgras }\end{array}$ \\
\hline $\begin{array}{l}\text { Vanggewas onderzaai } \\
\text { van gras en } \\
\text { vlinderbloemige } \\
\text { gewassen (cat. 3) }\end{array}$ & 0,3 & $\begin{array}{l}\text { - Grassoort(en) of vlinderbloemige gewassen } \\
\text { inzaaien als onderzaai in de hoofdteelt. Alle } \\
\text { soorten gras en vlinderbloemige gewassen zijn } \\
\text { toegestaan. Dit hoeft geen mengsel te zijn van } \\
\text { verschillende soorten. Kijk voor de toegestane } \\
\text { soorten in de tabel Gewascodes en GLB } 2019 \text {. } \\
\text { - Gelijktijdig met de hoofdteelt inzaaien en de } \\
\text { hoofdteelt uiterlijk } 15 \text { oktober oogsten. Is de } \\
\text { hoofdteelt een wintergewas dat in de herfst van } \\
\text { het voorgaande jaar al is gezaaid en dit jaar } \\
\text { wordt geoogst? Dan hoeft de onderzaai niet } \\
\text { gelijktijdig met de hoofdteelt ingezaaid worden. } \\
\text { De onderzaai van het vanggewas mag dan ook } \\
\text { in het voorjaar voor } 15 \text { mei plaatsvinden. } \\
\text { - Oogst u de hoofdteelt later dan u heeft } \\
\text { opgegeven in de Gecombineerde opgave? Dan } \\
\text { meldt u de werkelijke oogstdatum uiterlijk op de } \\
\text { dag die u aanvankelijk als oogstmoment had } \\
\text { opgegeven. Oogst u de hoofdteelt eerder dan u } \\
\text { heeft opgegeven in de Gecombineerde opgave? } \\
\text { Dan meldt u de werkelijke oogstdatum uiterlijk } \\
\text { op de dag van de oogst. } \\
\text { - Minimaal } 8 \text { weken op het land, tenzij er binnen } \\
\text { die } 8 \text { weken een nieuw gewas (hoofdteelt) op } \\
\text { het perceel wordt ingezaaid. Tijdens de } \\
8 \text { wekenperiode geen activiteiten verrichten die } \\
\text { het gewas en de doelstelling ervan (stikstof } \\
\text { opvangen) kunnen beschadigen. O.a. begrazen, } \\
\text { maaien/klepelen zijn niet toegestaan. Maar } \\
\text { maaien en begrazen zijn toegestaan mits de } \\
\text { van de volgende hoofdteelt. }\end{array}$ & \\
\hline $\begin{array}{l}\text { (Onbeheerde) } \\
\text { akkerrand bufferstrook }\end{array}$ & 1 & $\begin{array}{l}\text { - Grens met lange zijde aan of ligt op bouwland } \\
\text { dat boer zelf in gebruik heeft. } \\
\text { - Is ten minste } 1 \mathrm{~m} \text { breed en telt mee voor } \\
\text { maximaal } 20 \mathrm{~m} \text {. Daarnaast moet de rand in het } \\
\text { veld duidelijk te onderscheiden zijn van de rest } \\
\text { van het bouwland. } \\
\text { - Geen landbouwproductie (niet oogsten, } \\
\text { begrazen of maaien). Maaien mag alleen als het } \\
\text { maaisel blijft liggen. } \\
\text { - Moet } \mathrm{t} / \mathrm{m} 31 \text { december intact blijven. Bij direct } \\
\text { aansluitend telen van een wintergewas moet de } \\
\text { akkerrand intact blijven } \mathrm{t} / \mathrm{m} 31 \text { augustus. }\end{array}$ & $\begin{array}{l}\text { Ingetekende werkelijke } \\
\text { oppervlakte telt mee als EA }\end{array}$ \\
\hline
\end{tabular}




\begin{tabular}{|c|c|c|c|}
\hline Tyре EA & $\begin{array}{l}\text { Wegings- } \\
\text { factor }\end{array}$ & Voorwaarden & Toegestane soorten \\
\hline & & $\begin{array}{l}\text { - Rand moet ondergeschikt zijn aan het } \\
\text { - } \text { Eeofdperceel. } \\
\text { watergang. Bij een bufferstrook telt ook de } \\
\text { oevervegetatie tot aan de waterlijn mee. } \\
\text { - Een oevervegetatie is geen subsidiabele } \\
\text { landbouwgrond en geeft u daarom als een } \\
\text { bufferstrook op in de Gecombineerde opgave. } \\
\text { - Een onbeheerde akkerrand die ligt op } \\
\text { subsidiabele landbouwgrond geeft u op in de } \\
\text { Gecombineerde opgave als onbeheerde } \\
\text { akkerrand. Een oevervegetatie telt niet mee. } \\
\text { - Een onbeheerde akkerrand die ligt op niet- } \\
\text { subsidiabele landbouwgrond geeft u op in de } \\
\text { Gecombineerde opgave als bufferstrook. Een } \\
\text { oevervegetatie telt mee. } \\
\text { - Het opgeven van een onbeheerde rand met } \\
\text { daarnaast een bufferstrook mag. Het totaal telt } \\
\text { mee voor maximaal } \\
20 \text { m breed. } \\
\text { alleen als deze in eigen beheer is en } \\
\text { ondergeschikt is aan hoofdteelt. }\end{array}$ & \\
\hline $\begin{array}{l}\text { Stroken bouwland } \\
\text { langs bos }\end{array}$ & 1 & $\begin{array}{l}\text { - De strook ligt op subsidiabel bouwland dat u zelf } \\
\text { in gebruik heeft en grenst met de lange zijde } \\
\text { direct aan bos. Er mag geen sloot of iets anders } \\
\text { tussen strook en bos liggen. } \\
\text { - De strook is minimaal } 1 \mathrm{~m} \text { breed en mag } \\
\text { meetellen voor EA tot maximaal } 20 \text { m breed. } \\
\text { - De strook wordt niet gebruikt voor } \\
\text { landbouwproductie (niet oogsten, begrazen of } \\
\text { maaien). Maaien mag alleen als het maaisel } \\
\text { blijft liggen. } \\
\text { - De strook moet het hele jaar intact blijven. }\end{array}$ & $\begin{array}{l}\text { Ingetekende (werkelijke) } \\
\text { oppervlakte telt mee tot } \\
\text { maximaal } 20 \text { m breed }\end{array}$ \\
\hline Vijvers/poelen & 1,5 & $\begin{array}{l}\text { - De maximale oppervlakte voor een vijver die } \\
\text { mag meetellen voor EA is van 0,1 ha naar } \\
\text { 0,3 ha gegaan in } 2018 \text {. } \\
\text { - Geen reservoir van beton/plastic. } \\
\text { - Oevervegetatie tot waterlijn mag worden } \\
\text { meegerekend. }\end{array}$ & $\begin{array}{l}\text { Ingetekende werkelijk } \\
\text { oppervlakte telt mee als EA }\end{array}$ \\
\hline Heggen/houtwallen & 2 & $\begin{array}{l}\text { - Vanaf } 2018 \text { tellen heggen en houtwallen (en } \\
\text { bomen in rijen) voortaan mee tot een breedte } \\
\text { van maximaal } 10 \mathrm{~m} \text { en met een } \\
\text { standaardoppervlakte van } 5 \mathrm{~m}^{2} \text { per meter } \\
\text { lengte. Ook als het om een combinatie van deze } \\
\text { elementen naast elkaar gaat. }\end{array}$ & $\begin{array}{l}\text { Ingetekende werkelijk } \\
\text { oppervlakte telt mee als EA }\end{array}$ \\
\hline $\begin{array}{l}\text { Bomen in rij/ } \\
\text { windhaag }\end{array}$ & 2 & $\begin{array}{l}\text { - Tussen de kruinen niet meer dan } 5 \mathrm{~m} \text {. } \\
\text { - Windhaag in perceel fruitteelt. } \\
\text { - Vanaf } 2018 \text { tellen bomen in rijen voortaan mee } \\
\text { tot een breedte van maximaal } 10 \mathrm{~m} \text { en met een } \\
\text { standaardoppervlakte van } 5 \mathrm{~m}^{2} \text { per meter } \\
\text { lengte. }\end{array}$ & $\begin{array}{l}\text { Standaardoppervlakte } \\
5 \mathrm{~m}^{2} \text { per } \mathrm{m} \text { lengte }\end{array}$ \\
\hline $\begin{array}{l}\text { Geïsoleerde bomen en } \\
\text { knotbomen }\end{array}$ & 1,5 & $\begin{array}{l}\text { - Knotbomen die voor knotten diameter van } 4 \text { m } \\
\text { hebben, vallen hier ook onder. }\end{array}$ & $\begin{array}{l}\text { Standaardoppervlakte } \\
20 \mathrm{~m}^{2} \text { per boom }\end{array}$ \\
\hline Boomgroepen & 1,5 & $\begin{array}{l}\text { - Overlappende kruinen } \\
\text { - Bij boomgroepen tellen struiken of stenen vanaf } \\
2018 \text { ook mee. De maximale oppervlakte die } \\
\text { voor boomgroepen inclusief bomen en stenen } \\
\text { meetelt, blijft factor } 3 \text {. }\end{array}$ & $\begin{array}{l}\text { Ingetekende werkelijk } \\
\text { oppervlakte telt mee als EA }\end{array}$ \\
\hline
\end{tabular}




\section{Bijlage 3 Overzicht output- en resultaatindicatoren voor monitoring vergroening in GLB}

Tabel B3.1 Overzicht van de aanvullingen op de outputindicatoren van het GTEK voor nationale invulling vergroening (uit Van Doorn et al., 2015).

\begin{tabular}{|c|c|c|}
\hline Maatregel & GTEK-indicator (t.b.v. EU-monitoring) & $\begin{array}{l}\text { Aanvulling (Van Doorn et al., } \\
\text { 2015) t.b.v. nationale monitoring } \\
\text { en evaluatie van vergroening }\end{array}$ \\
\hline \multirow[t]{2}{*}{ Vergroening } & $\begin{array}{l}\text { Totaalaantal boeren dat ten minste één } \\
\text { vergroeningsverplichting heeft. }\end{array}$ & - \\
\hline & $\begin{array}{l}\text { Totaalareaal met betalingsrecht behorende bij de } \\
\text { vergroeningsplichtige boeren. }\end{array}$ & - \\
\hline \multirow[t]{2}{*}{$\begin{array}{l}\text { Vrijstelling van } \\
\text { vergroening }\end{array}$} & $\begin{array}{l}\text { Aantal boeren dat vrijgesteld is van de vergroening: } \\
\text { biologische boeren en bedrijven vallend onder de } \\
\text { drempelwaarden voor gewasdiversificatie en EA. }\end{array}$ & - \\
\hline & $\begin{array}{l}\text { Totaalareaal met betalingsrechten behorende bij de } \\
\text { vrijgestelde boeren. }\end{array}$ & - \\
\hline \multirow[t]{2}{*}{ Gewasdiversificatie } & $\begin{array}{l}\text { Aantal boeren dat zich aan de gewasdiversificatie moet } \\
\text { houden (aantal met } 2 \text { gewassen, aantal met } 3 \text { gewassen). }\end{array}$ & - \\
\hline & $\begin{array}{l}\text { Totaalareaal met toeslagrechten behorende bij de } \\
\text { vergroeningsplichtige boeren met gewasdiversificatie. }\end{array}$ & - \\
\hline \multirow[t]{5}{*}{ Blijvend grasland } & Aantal boeren met blijvend grasland. & \\
\hline & $\begin{array}{l}\text { Opgegeven areaal blijvend grasland behorend bij de } \\
\text { toeslaggerechtigde boeren. }\end{array}$ & Areaal 'werkelijk' blijvend grasland \\
\hline & $\begin{array}{l}\text { Aantal boeren met blijvend grasland in aangewezen } \\
\text { kwetsbare gebieden (Natura 2000). }\end{array}$ & - \\
\hline & $\begin{array}{l}\text { Aantal opgegeven ha blijvend grasland in aangewezen } \\
\text { kwetsbare gebieden. }\end{array}$ & $\begin{array}{l}\text { + ruimtelijke informatie } \\
\text { (perceelniveau) }\end{array}$ \\
\hline & $\begin{array}{l}\text { Totaalaantal ha blijvend grasland in overige kwetsbare } \\
\text { gebieden (buiten Natura 2000). }\end{array}$ & $\begin{array}{l}\text { Aantal ha HNV-grasland niet vallend } \\
\text { onder de aangewezen kwetsbare } \\
\text { gebieden }\end{array}$ \\
\hline \multirow[t]{3}{*}{$\begin{array}{l}\text { Ecologische } \\
\text { Aandachtsgebieden (EA) }\end{array}$} & Aantal boeren met EA-verplichting. & $\begin{array}{l}\% \text { individueel/collectief/ regionaal } \\
\text { ingevuld }\end{array}$ \\
\hline & Areaal opgegeven bouwland met EA-verplichting. & $\begin{array}{l}\text { + ruimtelijke informatie } \\
\text { (perceelniveau) }\end{array}$ \\
\hline & $\begin{array}{l}\text { Areaal opgegeven EA, per EA-type: } \\
\text { - Equivalent pakket (beheerde akkerrand + } \\
\text { landschapselement/sloot of vogelakker) } \\
\text { - Onbeheerde akkerranden } \\
\text { - Stikstof-/eiwitgewassen } \\
\text { - Vanggewassen } \\
\text { - Wilgenhakhout } \\
\text { - Landschapselementen }\end{array}$ & $\begin{array}{l}\text { + ruimtelijke informatie } \\
\text { (perceelniveau) }\end{array}$ \\
\hline Equivalente maatregelen & $\begin{array}{l}\text { Aantal boeren dat equivalente maatregelen opgeeft } \\
\text { (certificering of ANB) \& opgegeven areaal. }\end{array}$ & $\begin{array}{l}\text { Specificering van de certificaten dan } \\
\text { wel ANB-maatregelen die opgegeven } \\
\text { zijn: } \\
\text { - Akkerrand of vogelakker } \\
\text { - Veldleeuwerik } \\
\text { - Vezelhenneppakket }\end{array}$ \\
\hline
\end{tabular}


Tabel B3.2 Overzicht van de aanvullingen op de resultaatindicatoren van het GTEK voor nationale invulling vergroening (uit Van Doorn et al., 2015).

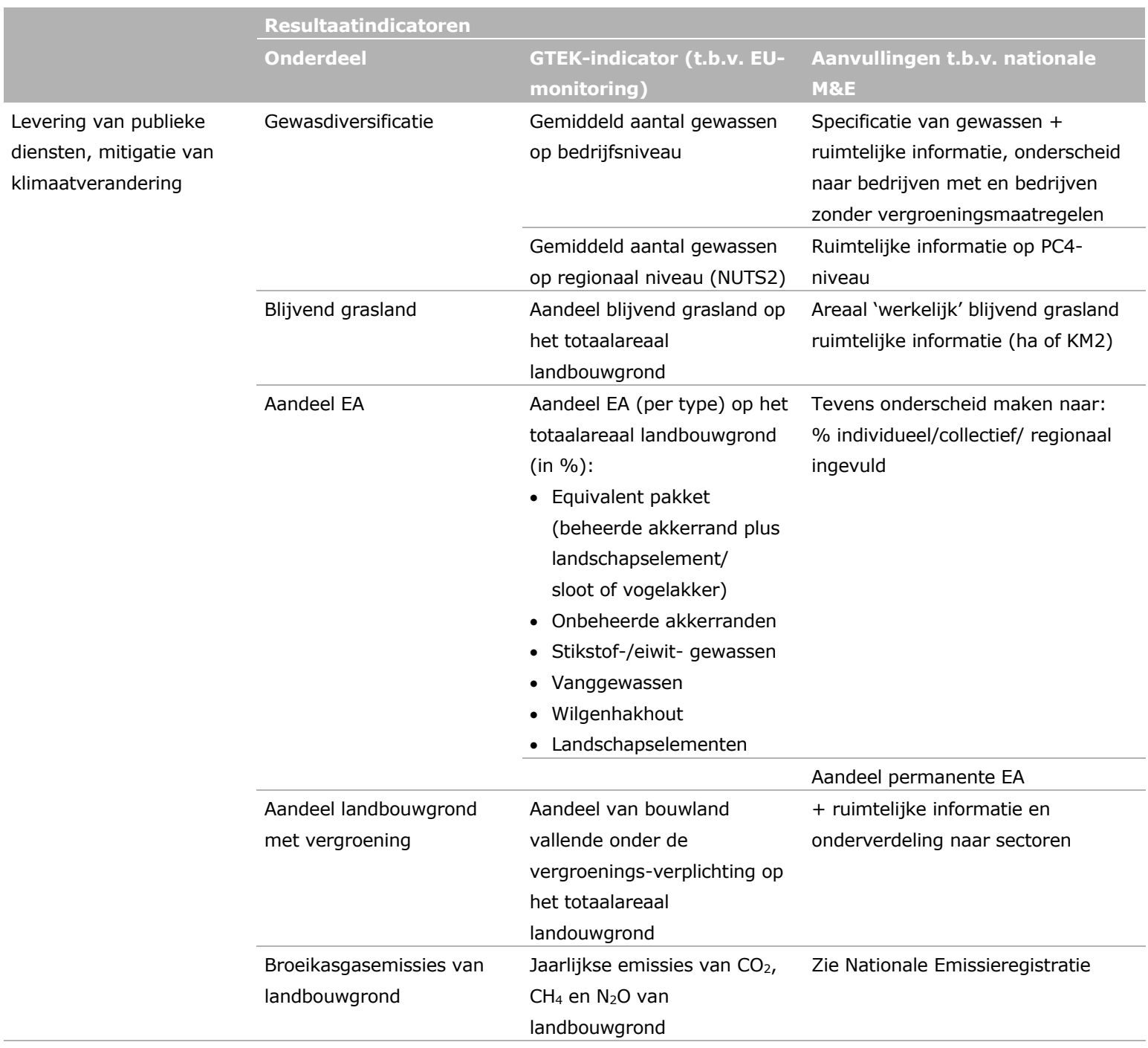


Wageningen Environmental Research Postbus 47

6700 AA Wageningen

T 0317480700

www.wur.nl/environmental-research

Wageningen Environmental Research

Rapport 3119

ISSN 1566-7197
De missie van Wageningen University \& Research is 'To explore the potential of nature to improve the quality of life'. Binnen Wageningen University \& Research bundelen Wageningen University en gespecialiseerde onderzoeksinstituten van Stichting Wageningen Research hun krachten om bij te dragen aan de oplossing van belangrijke vragen in het domein van gezonde voeding en leefomgeving. Met ongeveer 30 vestigingen, 6.800 medewerkers ( $6.000 \mathrm{fte}$ ) en 12.900 studenten behoort Wageningen University \& Research wereldwijd tot de aansprekende kennisinstellingen binnen haar domein. De integrale benadering van de vraagstukken en de samenwerking tussen verschillende disciplines vormen het hart van de unieke Wageningen aanpak. 


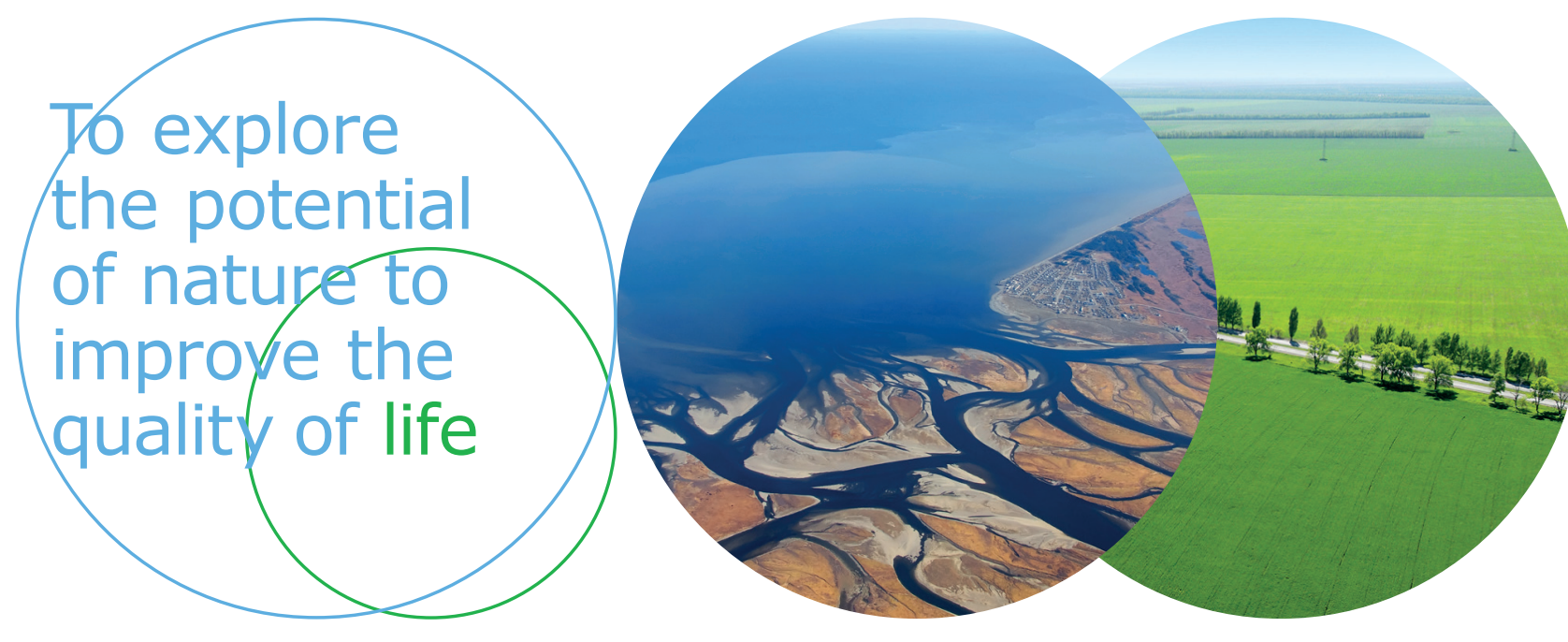

Wageningen Environmental Research Postbus 47

$6700 \mathrm{AB}$ Wageningen

T 317480700

www.wur.nl/environmental-research

Rapport 3119

ISSN 1566-7197
De missie van Wageningen University \& Research is 'To explore the potential of nature to improve the quality of life'. Binnen Wageningen University \& Research bundelen Wageningen University en gespecialiseerde onderzoeksinstituten van Stichting Wageningen Research hun krachten om bij te dragen aan de oplossing van belangrijke vragen in het domein van gezonde voeding en leefomgeving. Met ongeveer 30 vestigingen, 6.800 medewerkers (6.000 fte) en 12.900 studenten behoort Wageningen University \& Research wereldwijd tot de aansprekende kennisinstellingen binnen haar domein. De integrale benadering van de vraagstukken en de samenwerking tussen verschillende disciplines vormen het hart van de unieke Wageningen aanpak. 